\title{
Tropical tropospheric ozone columns from nadir retrievals of GOME-1/ERS-2, SCIAMACHY/Envisat, and GOME-2/MetOp-A (1996-2012)
}

\author{
Elpida Leventidou, Kai-Uwe Eichmann, Mark Weber, and John P. Burrows \\ Institute of Environmental Physics (IUP), University of Bremen, Bremen, Germany \\ Correspondence to: Elpida Leventidou (levent@iup.physik.uni-bremen.de)
}

Received: 21 December 2015 - Published in Atmos. Meas. Tech. Discuss.: 18 January 2016

Revised: 20 June 2016 - Accepted: 4 July 2016 - Published: 28 July 2016

\begin{abstract}
Tropical tropospheric ozone columns are retrieved with the convective cloud differential (CCD) technique using total ozone columns and cloud parameters from different European satellite instruments. Monthly mean tropospheric column amounts [DU] are calculated by subtracting the above-cloud ozone column from the total column. A CCD algorithm (CCD_IUP) has been developed as part of the verification algorithm developed for TROPOspheric Monitoring Instrument (TROPOMI) on Sentinel 5-precursor (S5p) mission, which was applied to GOME/ERS-2 (1995-2003), SCIAMACHY/ Envisat (20022012), and GOME-2/MetOp-A (2007-2012) measurements. Thus a unique long-term record of monthly-mean tropical tropospheric ozone columns $\left(20^{\circ} \mathrm{S}-20^{\circ} \mathrm{N}\right)$ from 1996 to 2012 is now available. An uncertainty estimation has been performed, resulting in a tropospheric ozone column uncertainty less than $2 \mathrm{DU}(<10 \%)$ for all instruments. The dataset has not been yet harmonised into one consistent; however, comparison between the three separate datasets (GOME/SCIAMACHY/GOME-2) shows that GOME-2 overestimates the tropical tropospheric ozone columns by about $8 \mathrm{DU}$, while SCIAMACHY and GOME are in good agreement. Validation with Southern Hemisphere ADditional OZonesondes (SHADOZ) data shows that tropospheric ozone columns from the CCD_IUP technique and collocated integrated ozonesonde profiles from the surface up to $200 \mathrm{hPa}$ are in good agreement with respect to range, interannual variations, and variances. Biases within $\pm 5 \mathrm{DU}$ and root-mean-square (RMS) deviation of less than $10 \mathrm{DU}$ are found for all instruments. CCD comparisons using SCIAMACHY data with tropospheric ozone columns derived from
\end{abstract}

limb/nadir matching have shown that the bias and RMS deviation are within the range of the CCD_IUP comparison with the ozonesondes. The 17-year dataset can be helpful for evaluating chemistry models and performing climate change studies.

\section{Introduction}

Stratospheric ozone is well known for protecting the surface from harmful ultraviolet solar radiation. However, ozone in the troposphere plays a more complex role. Although a small amount of ozone of about $500 \mathrm{Tg} \mathrm{yr}^{-1}$ enters the troposphere either by stratospheric intrusions at midlatitudes or by wave breaking in the subtropics (IPCC, 2007), tropospheric ozone levels cannot be explained by the stratosphere-troposphere exchange (STE) processes alone (Crutzen, 1995; Jacob, 2000). Unlike other greenhouse gases, ozone is a secondary pollutant produced exclusively in the atmosphere with a flux of $3420 \pm 770 \mathrm{Tg} \mathrm{yr}^{-1}$ (IPCC, 2007). It is mainly generated from the photochemical oxidation of four major precursors: carbon monoxide $(\mathrm{CO})$, methane $\left(\mathrm{CH}_{4}\right)$, volatile organic compounds (VOCs), and non-methane volatile organic compounds (NMVOCs) which are produced in the presence of nitrogen oxides $\left(\mathrm{NO}_{x}=\mathrm{NO}+\mathrm{NO}_{2}\right)$. These ozone precursors are emitted in large quantities due to human activities, such as traffic, fossil fuel combustion, industry, and biomass burning. During the so-called biomass burning seasons (September-October in southern Africa and South America and December-January over Northern Africa) the ozone precursor emissions maximise (Ziemke et al., 2009b). 
However, the location and magnitude of these fires varies during El Niño-Southern Oscillation (ENSO) events (Chandra et al., 2009). In the tropics, the largest source of VOCs and NMVOCs is by far natural emission from vegetation (tropical forests and savannah) and in smaller amounts from the oceans (IPCC, 2013). Considerable amounts of $\mathrm{NO}_{x}$ in the tropics are also produced by lightning (upper troposphere, UT), natural savannah burning, and microbial nitrification and denitrification of the soil (Seinfeld and Pandis, 2006; Jacob, 2000; Schumann and Huntrieser, 2007).

Tropospheric ozone plays a crucial role in the Earth's atmosphere. In the UT, ozone is an important greenhouse gas with an estimated global-averaged radiative forcing of $0.40 \pm 0.20 \mathrm{~W} \mathrm{~m}^{-2}$ (Stevenson et al., 2013; IPCC, 2013), and it contributes greatly to the oxidation efficiency of the atmosphere. Ozone is the primary tropospheric source of hydroxyl $(\mathrm{OH})$ and peroxy $\left(\mathrm{RO}_{x}\right)$ radicals, which affect the lifetime of other greenhouse gases such as methane $\mathrm{CH}_{4}$ (Crutzen, 1974; Shindell et al., 2009; Cooper et al., 2014). In the lower troposphere, close to the ground, ozone can be extremely harmful for human health as it can oxidise biological tissues and causes respiratory problems. Especially in smog events, with abnormally high concentrations, it can even be deadly (WHO, 2013).

Tropospheric ozone presents considerable variability mainly due to its chemical lifetime, which coincides with the timescales of weather systems. The global-averaged tropospheric ozone lifetime is $22 \pm 2$ days (Stevenson et al., 2006). In contrast, ozone's lifetime in the boundary layer is much shorter (a few hours) because it is more likely to be destroyed by surface deposition and chemical reactions, whereas in the middle and UT its lifetime is on the order of weeks to months (Cooper et al., 2014). There are several ways that convection impacts on tropospheric ozone and its precursors. First, convection can redistribute tropospheric ozone burden via vertical mixing. Lower tropospheric ozone is lifted up to the UT where ozone lifetime is longer, while, due to mass balance conservation, UT air rich in $\mathrm{O}_{3}$ mixes and submerges into regions where ozone lifetime is shorter. As a result, the UT $\mathrm{O}_{3}$ as well as the overall tropospheric $\mathrm{O}_{3}$ column decreases (Doherty et al., 2005). Second, convective systems such as tropical cyclones can transport ozone precursors many kilometres away from their source, resulting in ozone production in remote areas where it builds up (Sauvage et al., 2006).

Tropospheric ozone exhibits a profound wave-one pattern, with high values over the South Atlantic ( 30-40 DU) and low values over the Indian and Pacific oceans ( $\sim 10-20$ DU). This feature is persistent with a maximum in autumn (austral spring). This is a result of several reasons, such as the dynamical redistribution of ozone precursors from biomass burning from the African and South American continent to the mid-Atlantic. The main dynamical features in that region are the African easterly jet (AEJ) and the St. Helene high, which lead to a redistribution of ozone from Northern Africa to the area around Namibia (Diab et al., 2003).
Whereas both the southwesterly Harmattan flow and the AEJ bring high ozone from the ground up to $600 \mathrm{hPa}$ over the African continent, only the AEJ advection exports high ozone over the North Atlantic (Sauvage et al., 2006). Furthermore, upper-tropospheric ozone production from lightning $\mathrm{NO}_{x}$ sediments is stronger over the southern tropical Atlantic as part of the Walker circulation and is weaker over upwelling regions such as the tropical Pacific (Martin et al., 2002). Tropospheric ozone over the tropical Pacific presents a persistent minimum due to ozone loss reactions that are favoured by the specific conditions dominating there, such as the high marine boundary layer air temperature and the low overhead ozone. These conditions favour the strong advection from east to west by the Walker circulation. For this reason the tropospheric air masses have been in a clean, warm, and humid environment for a long time and loss of odd oxygen, ozone, and ozone precursors like $\mathrm{NO}_{x}\left(=\mathrm{NO}+\mathrm{NO}_{2}\right.$; $\mathrm{NO}_{x}$ is lost by conversion into $\mathrm{HNO}_{3}$ followed by washout) proceeded longer than elsewhere in the tropics (Rex et al., 2014).

Ozone is removed from the troposphere by several chemical reactions $\left(3470 \pm 520 \mathrm{Tg} \mathrm{yr}^{-1}\right)$ or is dry deposited $(770 \pm$ $180 \mathrm{Tg} \mathrm{yr}^{-1}$ ) at the surface (IPCC, 2007). Nevertheless, world population growth and industrialisation have led to a strong increase in anthropogenic emissions, resulting in an increase in the tropospheric ozone burden $(300 \pm 30 \mathrm{Tg}$; IPCC, 2007) by 1-7\% per decade in the tropics (Beig and Singh, 2007; Cooper et al., 2014). Undoubtedly, the need to control the tropospheric ozone increase is crucial. Every potential monitor and study of long-term tropospheric $\mathrm{O}_{3}$ changes as well as the quantification of associated radiative forcing using chemical transport or climate models have to rely on the availability of reliable tropospheric ozone data.

Remote sensing from satellites has been proven to be very useful in providing consistent information of tropospheric ozone concentrations over large areas. Tropospheric ozone was first retrieved from space with the so-called residual method. The stratospheric ozone column above 100 mbar retrieved from the Stratospheric Aerosol and Gas Experiment II (SAGE II) was subtracted from the total ozone column (TCO) retrieved from the Total Ozone Mapping Spectrometer (TOMS) aboard the Nimbus 7 satellite (Fishman et al., 1990). The following years several other methods have been developed, such as the cloud slicing (CS) technique (Ziemke et al., 2001). The later technique was first applied using above-cloud column ozone measurements from the TOMS instrument in combination with temperature-humidity and infrared radiometer (THIR) cloud-top pressure data, onboard the Nimbus-7 satellite. The CS takes advantage of the almost opaque property of water vapour clouds to ultraviolet wavelength radiation in order to derive ozone column amounts in the UT. Later, the CS method was applied to ozone and cloud data from the Ozone Monitoring Instrument (OMI) (Ziemke et al., 2008) and from the Global Ozone Monitoring Experiment-2 (GOME-2) (Valks et al., 2014) to derive 
ozone mixing ratios inside deep convective clouds (DCCs) and proved that very low ozone amounts exist inside these clouds over the Indian Ocean and the western Pacific Ocean. Kim et al. (2001) developed the scan-angle method (SAM) applied on TOMS data. The method was based on the physical differences in ozone column detection as a function of its scan-angle geometry. The difference in TOMS retrieval information between nadir and high viewing angles maximises in the troposphere with a peak near an altitude of $5 \mathrm{~km}$. This analysis suggests that the total ozone difference between two viewing angles contains information about tropospheric ozone. Another residual approach to retrieve tropospheric ozone has been applied to OMI total column ozone measurements in combination with Aura Microwave Limb Sounder (MLS) stratospheric column ozone measurements producing global maps of OMI/MLS tropospheric ozone (Ziemke et al., 2006). Tropospheric ozone data have been also produced with the limb/nadir-matching (LNM) technique (Sierk et al., 2006; Ebojie et al., 2014), which benefits from the most important feature of SCIAMACHY: the possibility to observe the same atmospheric volume first in limb and then (after about $7 \mathrm{~min}$ ) in nadir geometry. With the knowledge of the tropopause height, the tropospheric $\mathrm{O}_{3}$ can be retrieved by subtracting the stratospheric (limb) from the total (nadir) $\mathrm{O}_{3}$ columns. Equally important attempts to retrieve tropospheric ozone have been made using thermal infrared emission instruments, such as the Infrared Atmospheric Sounding Interferometer (IASI) on MetOp-A (Keim et al., 2009; Boynard et al., 2009) or a combination of infrared with ultraviolet (UV) measurements (Burrows et al., 2004; Cuesta et al., 2013).

The present study focuses on the convective cloud differential (CCD) method which was first developed by Ziemke et al. (1998) and applied to TOMS (1979-2005) and OMI ozone data (since 2004) (Ziemke and Chandra, 2012). The technique uses above-cloud (reflectivity $>0.9$ ) and clearsky (reflectivity $<0.2$ ) ozone column measurements to derive monthly-mean tropical tropospheric ozone columns. The cloudy measurements above the western Pacific and the Indian oceans represent stratospheric ozone, which is assumed to be independent of longitude in the tropics. In a subsequent step, the monthly-mean above-cloud ozone columns (AC$\mathrm{COs}$ ) are subtracted from the cloud-free TCOs, assuming a zonally invariant stratospheric column, resulting in monthly averaged tropical tropospheric columns of ozone (TTCO). The same method was improved and applied to GOME (Valks et al., 2003) and GOME-2 data by Valks et al. (2014). In contrast to TOMS, GOME was able to determine cloud fractions (CFs), cloud albedos, and cloud-top pressures by using spectral measurements in the near-infrared wavelength (oxygen A-band) region combined with broadband spectral data from polarisation measurement devices that have better spatial resolution than the spectra used in trace gas retrievals. By combining the cloud information with ozone column measurements, monthly-mean values of the tropical tropospheric ozone columns have been determined.
Here, we present the results of our CCD algorithm (CCD_IUP) using TCO data retrieved with the WFDOAS (weighting function differential optical absorption spectroscopy) (Coldewey-Egbers et al., 2005) algorithm applied on spectra from the series of European satellite instruments GOME, SCIAMACHY, and GOME-2/MetOp-A, spanning a time period of 17 years (1996-2012). The CCD_IUP algorithm has been initially developed as a verification algorithm for S5P_TROPOZ_CCD prototype algorithm within the framework of the TROPOMI algorithm development, which is based upon the Valks et al. algorithm (S5P/TROPOMI Science Verification Report, 2015). The scope of the verification is to identify possible deficiencies and highlight potential improvements. Both algorithms were applied to operational GOME-2 GDP 4.7 data. The agreement between them was found to be very good $(0.9<R<0.99$, root-mean-square (RMS) error between 4 and $9 \mathrm{DU}$, and biases less than $2 \mathrm{DU}$ in most of the cases).

The current manuscript is structured as follows. In Sect. 2, we present the data that have been used in the CCD technique (total ozone, $\mathrm{CF}$, and $\mathrm{CTH}$ ). In Sect. 3, we describe the CCD technique and the modifications we made to the method applied in the past by Ziemke et al. (1998) and Valks et al. (2003, 2014). In Sect. 4, we provide the uncertainty budget. Section 5 presents the tropospheric ozone columns dataset (1996 to 2012) that has been created with the CCD_IUP algorithm. First validation results from comparisons to ozonesondes and SCIAMACHY limb/nadir matching are presented. Finally, Sect. 6 provides a summary and conclusions.

\section{The data}

GOME (Burrows et al., 1999), SCIAMACHY (Bovensmann et al., 1999), and GOME-2 (Callies et al., 2000) are three European passive satellite instruments that have measured the backscattered and reflected electromagnetic radiation from the atmosphere in nadir viewing mode (Table 1). These instruments have nearly identical spectral channels in the UV so that the same retrieval algorithm for total ozone and the derived tropospheric column ozone can be adopted without significant changes. While GOME and SCIAMACHY are already decommissioned, GOME-2 (MetOp-A, launched in 2006) and GOME-2B (MetOp-B, launched in 2012) still deliver data.

WFDOAS is used to retrieve TCOs from nadir spectra in the UV window from 326 to $335 \mathrm{~nm}$ (Coldewey-Egbers et al., 2005; Weber et al., 2005, 2013). The WFDOAS algorithm fits vertically integrated ozone weighting functions rather than ozone absorption cross sections to the sun-normalised radiances, which enables a direct retrieval of vertical column amounts (Coldewey-Egbers et al., 2005). The FRESCO algorithm, (Koelemeijer et al., 2001), is used to derive cloud properties such as CTH and CF for GOME. This cloud information is used to correct the retrieved TCOs for ozone below 
Table 1. Characteristics of the satellite instruments used.

\begin{tabular}{llll}
\hline Instruments & GOME/ERS-2 & SCIAMACHY/ENVISAT & GOME-2/MetOp-A \\
\hline Data period & $06 / 1995-07 / 2011^{*}$ & $08 / 2002-04 / 2012$ & $01 / 2007-$ present \\
Spectral coverage & $240-790 \mathrm{~nm}$ & $240-2380 \mathrm{~nm}$ & $240-790 \mathrm{~nm}$ \\
Ground pixel size & $320 \times 40 \mathrm{~km}^{2}$ & $60 \times 30 \mathrm{~km}^{2}$ & $40 \times 80 \mathrm{~km}^{2}$ \\
Equator crossing time & $10: 30$ & $10: 00$ & $9: 30$ \\
Global coverage & 3 days & 6 days & almost daily \\
\hline
\end{tabular}

* GOME global coverage lost in June 2003

the cloud layer that cannot be measured (Coldewey-Egbers et al., 2005). These cloud properties are also used to infer the tropospheric ozone column, which will be discussed later. A different cloud algorithm SACURA/OCRA (Kokhanovsky et al., 2005) is available for SCIAMACHY that retrieves CF, $\mathrm{CTH}$, and other cloud parameters from the oxygen A-band $(760 \mathrm{~nm})$. In WFDOAS the clouds are treated as Lambertian reflecting surfaces. The WFDOAS V2 has been also applied to GOME-2 spectral data (Weber et al., 2013) with the cloud properties being determined by the operational FRESCO+ algorithm (Wang et al., 2008). The agreement of WFDOAS total ozone for GOME and SCIAMACHY with ground data is within $\pm 1 \%$ (Bracheret et al., 2005; Weber et al., 2005, 2013).

\section{The CCD method}

The TTCO can be retrieved from satellite data with the CCD technique (Ziemke et al., 1998) using the total column of ozone and cloud information. Figure 1 illustrates the method and the considerations concerning the method that will be discussed in this section.

The original technique, as applied to TOMS data, assumes that the ACCO simulates the stratospheric ozone in the same latitude band and that this amount is invariant with longitude, which is approximately true in the tropics (Ziemke et al., 1998). The ACCO values over the Atlantic ocean $\left(45^{\circ} \mathrm{W}-\right.$ $45^{\circ} \mathrm{E}$ ) are overestimated due to the existence of less high clouds and more polluted background from biomass burning that is uplifted to the UTLS (upper troposphere and lower stratosphere) region (Sauvage et al., 2006; Avery et al., 2010). Therefore, the ACCO retrieval is limited to the western Pacific and Indian oceans $\left(70^{\circ} \mathrm{E}-170^{\circ} \mathrm{W}\right)$. However, a zonal variability of less than $\sim 5 \mathrm{DU}$ (Fig. 2) exists on monthly timescales in the tropical region. The stratospheric ozone column amount may be influenced by episodic tropical waves (Kelvin waves, mixed Rossby gravity waves, normal modes, and equatorial Rossby waves) in the stratosphere (Ziemke and Stanford, 1994). The assumption made in the original CCD method from Ziemke et al. (1998) that the stratospheric ozone column is independent of longitude in the tropics has been extensively investigated by Valks et al.

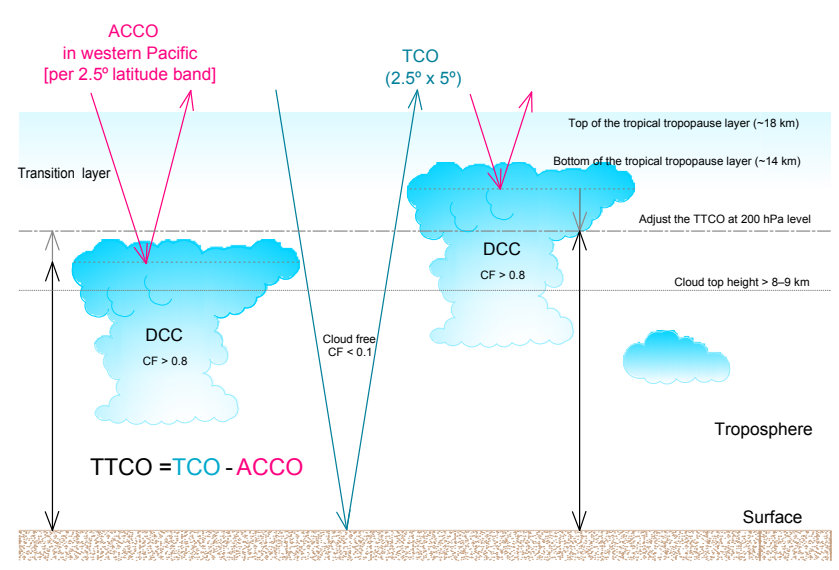

Figure 1. Illustration of the convective clouds differential (CCD) technique. DCC are the deep convective cloud, CF is the cloud fraction, ACCO is the above-cloud column of ozone, TCO is the total column of ozone and TTCO is the tropical tropospheric column of ozone.

(2003), where they conclude that it is valid above $200 \mathrm{hPa}$ in the tropics.

Another important factor causing the monthly variability of the ACCO is the natural variability of the DCC top height. The second basic assumption of the CCD method refers to the fact that the tropopause $(\sim 18 \mathrm{~km}$ or $\sim 100 \mathrm{hPa})$ lies close to the top of the DCC. These clouds are high, thick, and bright with greatest occurrence rates over the Intertropical Convergence Zone (ITCZ), the western Pacific Ocean, and the Indian Ocean (Sassen et al., 2009; Hong et al., 2007). Due to the immigration of the ITCZ, these clouds are located south, over the western and central Pacific Ocean, northern South America, and equatorial Africa in boreal winter and spring, whereas in boreal summer the highest DCC occurrences are located over the Indonesian region and the Bay of Bengal (Sassen et al., 2009). Figure 3a shows the distribution of the DCCs in January and August 2008 for SCIAMACHY $((\mathrm{CF}>0.8$ and $\mathrm{CTH}>9 \mathrm{~km})$ SACURA) and GOME-2 ((CF $>0.8$ and $\mathrm{CTH}>7 \mathrm{~km})$ FRESCO), indicating the ITCZ. Both instruments and cloud algorithms agree on the location of the DCCs but not on the number of the DCCs per grid box, mainly due to differences in the cloud algorithms used and the spatial resolution of the instru- 

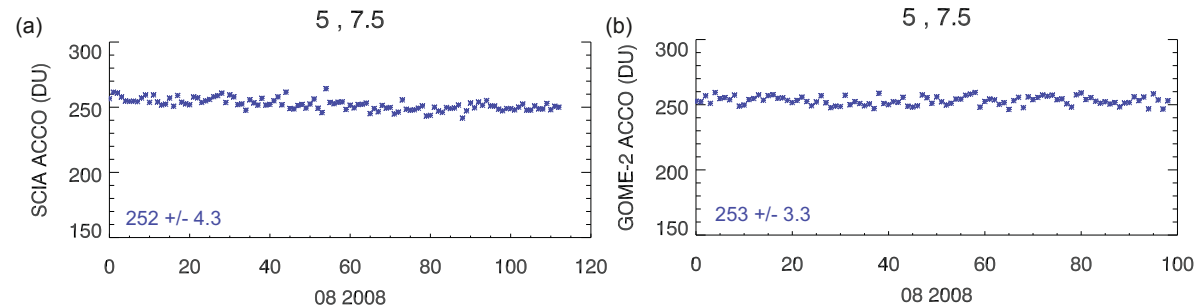

$-15,-12.5$
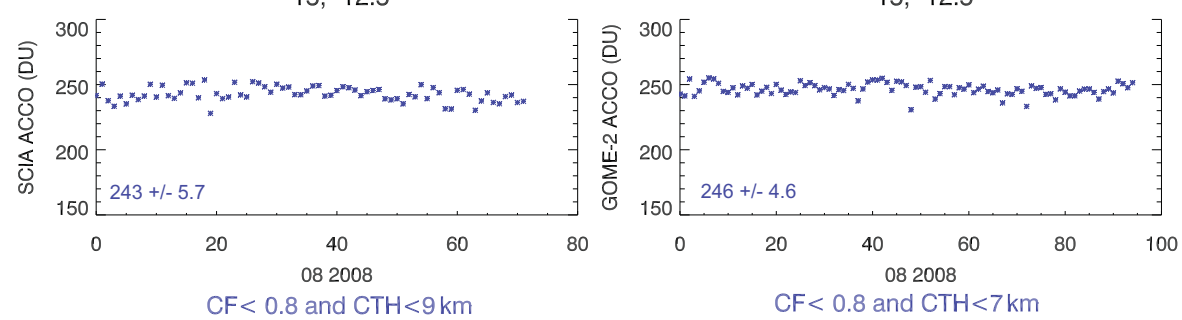

$\mathrm{CF}<0.8$ and $\mathrm{CTH}<7 \mathrm{~km}$

Figure 2. (a) Above-cloud column ozone (ACCO for the latitude bands $5-7.5^{\circ} \mathrm{N}$ and $15-12.5^{\circ} \mathrm{S}(\mathrm{CF}>0.8$ and $\mathrm{CTH}>9 \mathrm{~km})$ from $\mathrm{SCIA}-$ MACHY (using OCRA/SACURA for cloud detection). (b) Above-cloud column ozone (ACCO for the latitude bands 5-7.5 $\mathrm{N}$ and $15-$ $12.5^{\circ} \mathrm{S}(\mathrm{CF}>0.8$ and $\mathrm{CTH}>9 \mathrm{~km}$ ) from GOME-2 (using FRESCO for cloud detection) in August 2008. The $1 \sigma$ standard deviation is less than 5 DU.

(a) SCIAMACHY 012008
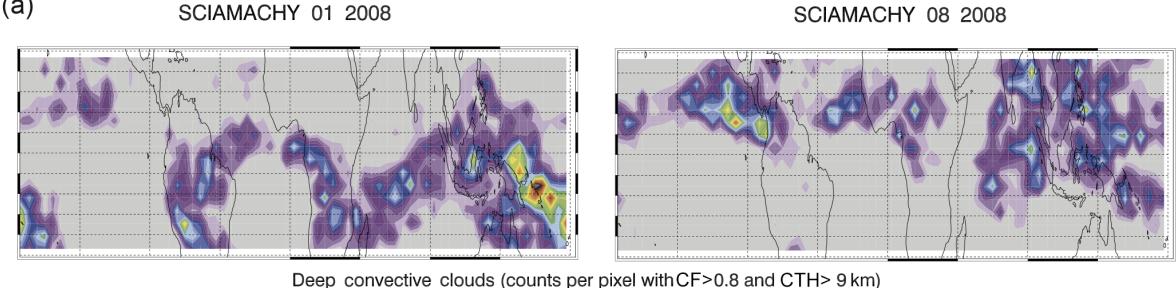

GOME 2012008

GOME 2082008
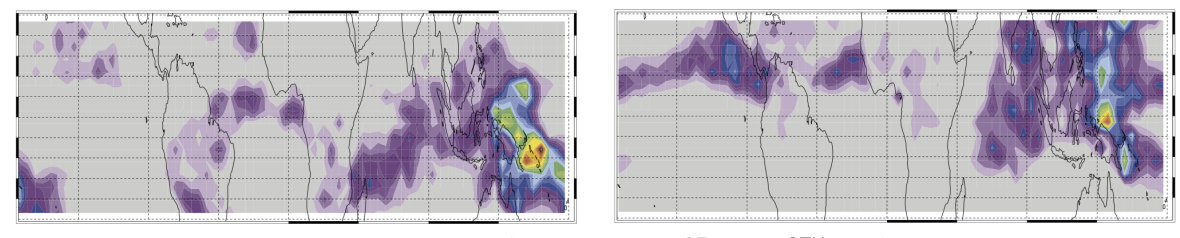

Deep convective clouds (counts per pixel with $\mathrm{CF}>0.8$ and $\mathrm{CTH}>7 \mathrm{~km}$ )

(b)
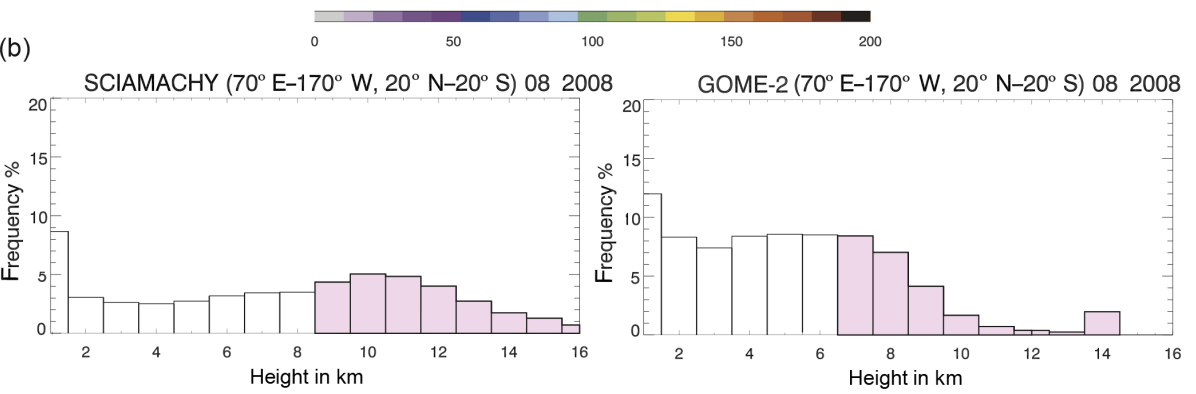

Figure 3. (a) The number of counts per grid box with CF greater than 0.8 and CTH greater than $9 \mathrm{~km}$ (SCIAMACHY) and CTH greater than $7 \mathrm{~km}$ (GOME-2) for January and August 2008. (b) Frequency of cloud-top heights (CTH) for August 2008 from SCIAMACHY (SACURA) and GOME-2 (FRESCO) in the western Pacific area $\left(20^{\circ} \mathrm{S}-20^{\circ} \mathrm{N}, 70^{\circ} \mathrm{E}-170^{\circ} \mathrm{W}\right)$. Pink shaded data are used for the ACCO calculation. 
ments. For example, several cloud algorithms like FRESCO (Koelemeijer et al., 2001) assume that clouds behave as opaque Lambertian surfaces, resulting usually in retrieving the effective (optical centroid) cloud-top height $(\mathrm{CTH}$; see Fig. 1) which lies below the physical CTH (Ziemke et al., 2008). SACURA CTH retrieval algorithm (Kokhanovsky et al., 2005), however, takes into account radiative transfer inside, above, and below the clouds (Lelli et al., 2014). Therefore, it provides more realistic CTHs. In order to define the DCCs we used measurements with CFs greater than 0.8 and CTHs greater than $9 \mathrm{~km}$ for SCIAMACHY and $7 \mathrm{~km}$ for GOME and GOME-2. Even with a higher CTH threshold for SCIAMACHY, SCIAMACHY has the highest frequency of "cloudy" measurements among the three satellites. Figure $3 \mathrm{~b}$ shows that roughly $\sim 25 \%$ of CTHs in the western Pacific are higher than $9 \mathrm{~km}$ for SACURA (SCIAMACHY), whereas for FRESCO (GOME-2) the same frequency is met for clouds only above $7 \mathrm{~km}$. Since the cloud algorithms differ between instruments and in order to have sufficient "cloudy" ozone measurements in more than $1 \%$ of all the measurements per latitude band, the lower CTH limit classifying the DCCs is different for each satellite instrument.

It is obvious that the different cloud algorithms calculate different $\mathrm{CFs}$ and CTHs and as a result yield different ACCO values (see Fig. 4a). However, it was concluded that the ACCO does not change significantly when the $\mathrm{CF}$ is greater than 0.8 and $\mathrm{CTH}$ greater than $7 \mathrm{~km}$. For the calculation of the ACCO, all "cloudy" measurements (defined separately for each instrument in order to have enough data) are selected and monthly averaged in latitude bands of width $2.5^{\circ}$ between -20 and $20^{\circ}$ in the western Pacific and Indian oceans $\left(70^{\circ} \mathrm{E}-170^{\circ} \mathrm{W}\right)$. Furthermore, it is known that most DCC tops only reach the bottom of the tropical tropopause layer or "tropical transition layer" (TTL) (Sherwood and Dessler, 2001; Gettelman and Forester, 2002; Fueglistaler et al., 2009), which is well below the thermal (cold point) tropopause $(\sim 150 \mathrm{hPa})$. Only on rare occasions do the DCCs overshoot the top of the TTL (Hong et al., 2007; Fueglistaler et al., 2009). Therefore, due to the natural variability of clouds, a climatological correction term is applied to each individual measurement of ACCO in order to correct for different CTHs and adjust the ACCO to a fixed level of $200 \mathrm{hPa}(\sim 12 \mathrm{~km})$. For the calculation of the column amount (Cor ${ }_{\mathrm{ACCO}}$ ), which adjusts the ACCO values to the $200 \mathrm{hPa}$ level, climatological ozone values from Fortuin and Kelder (1998) climatology were used.

The Fortuin and Kelder (1998) climatology is reported in volume mixing ratios (vmr) for specific pressure levels. In order to convert the volume mixing ratios (ppm) at the $i$ th level to Dobson units (DU), the following formula was used, taking into account the ideal gas law and the horizontal surface density (Ziemke et al., 2001):
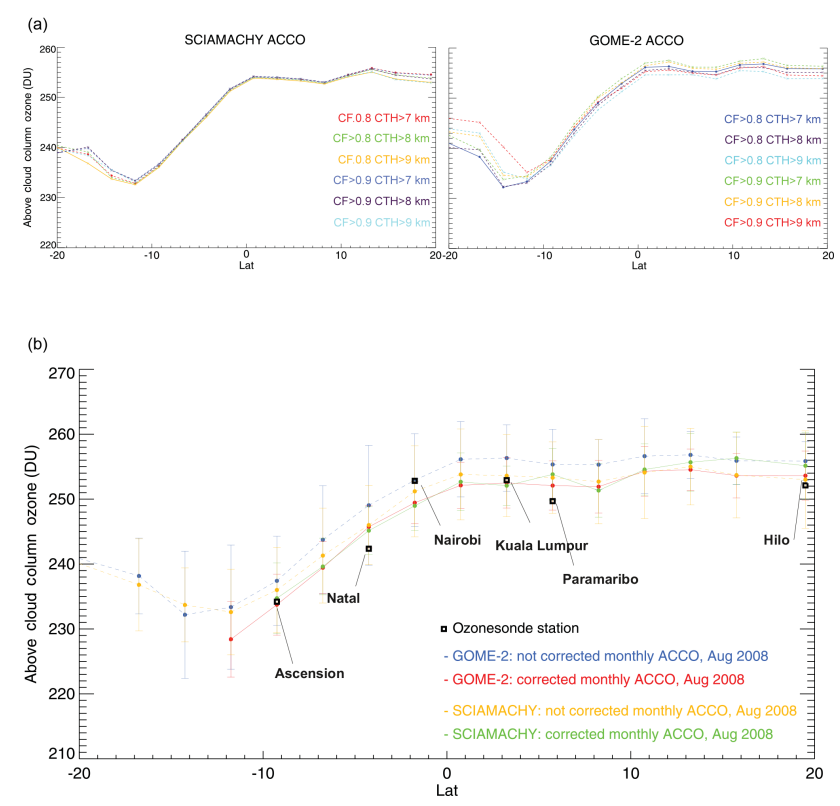

Figure 4. (a) SCIAMACHY (left) and GOME-2 (right) ACCO per $2.5^{\circ}$ latitude bands in the Indian and western Pacific Ocean $\left(70^{\circ} \mathrm{E}-170^{\circ} \mathrm{W}\right)$ for different cloud fractions $(0.8,0.9)$ and cloudtop heights $(7-9 \mathrm{~km})$ in August 2008. (b) Above-cloud column of ozone (ACCO) for $2.5^{\circ}$ latitude bands in the Indian and western Pacific Ocean from GOME-2 $(\mathrm{CF}>0.8$ and $\mathrm{CTH}>7 \mathrm{~km})$ and SCIAMACHY $(\mathrm{CF}>0.8$ and $\mathrm{CTH}>9 \mathrm{~km})$ in August 2008. Blue and yellow dashed lines are the zonal ACCO values before applying any corrections for GOME-2 and SCIAMACHY respectively. Red and green lines are the zonal ACCO values after corrections applied for adjusting to the $200 \mathrm{hPa}$ level and screening out outlier data. Error bars denote $1 \sigma$ standard deviation. Black boxes show the stratospheric ozone columns from ozonesondes, of the stations Ascension, Natal, Nairobi, Kuala Lumpur, Paramaribo, and Hilo.

$$
\begin{aligned}
& \operatorname{Cor}_{\mathrm{ACCO}}(i)=c \cdot 0.5 \\
& \quad \cdot[\operatorname{vmr}(i)+\operatorname{vmr}(i+1)] \cdot[p(i)-p(i+1)],
\end{aligned}
$$

where vmr is the volume mixing ratio (ppmv), $p$ is the pressure $(\mathrm{Pa})$, and

$c=\frac{k_{\mathrm{B}} \cdot T_{\mathrm{S}} \cdot N_{\mathrm{A}}}{\mu \cdot p_{\mathrm{S}} \cdot g}=0.7889\left[\mathrm{DUPa}^{-1} \mathrm{ppmv}^{-1}\right]$.

$T_{\mathrm{S}}$ is the standard temperature $(273.16 \mathrm{~K}), P_{\mathrm{S}}$ is the standard pressure $(101325 \mathrm{~Pa}), k_{\mathrm{B}}$ is Boltzmann's constant $\left(1.3806 \times 10^{23} \mathrm{~J} \mathrm{~K}^{-1}\right), \quad N_{\mathrm{A}}$ is Avogadro's number $\left(6.022 \times 10^{26}\right.$ molecules $\left.\mathrm{kmol}^{-1}\right), \mu$ is the mean molecular weight of the atmosphere (approximately 29), and $g$ is the mean acceleration of gravity $\left(9.81 \mathrm{~m} \mathrm{~s}^{-2}\right)$.

Finally, the vertical ozone column of the nearest pressure level as given in the ozone climatology to the retrieved CTH (pressure) measurement was used for the adjustment of the ACCO. 
- If CTP $<200 \mathrm{hPa}$ then $\mathrm{ACCO}^{\prime}=\mathrm{ACCO}+\mathrm{Cor}_{\mathrm{ACCO}}$

- If CTP $<200 \mathrm{hPa}$ then $\mathrm{ACCO}^{\prime}=\mathrm{ACCO}-\mathrm{Cor}_{\mathrm{ACCO}}$

The original CCD method developed by Ziemke et al. (1998) assumed that UV nadir satellite measuring instruments measure ozone above the top of the DCCs, something that is not completely true since UV radiation penetrates inside the cloud, resulting in an additional ozone absorption (Ziemke et al., 2008). The ozone concentrations inside the high reflective clouds at the regions of the tropical eastern Indian Ocean and western Pacific are about 4-7 ppbv (corresponding to an ozone column of $\sim 1 \mathrm{DU}$ between the mean cloud top and the $200 \mathrm{hPa}$ level). This is due to vertical convection of ozone-poor oceanic air from the marine boundary layer into the UT so that the error from ozone below the thermal tropopause is minimal if the retrieved ACCOs are taken from that region (Ziemke et al., 2008). For this reason, for the cases where CTP $>200 \mathrm{hPa}$ (for the reason discussed above, that FRESCO does not take into account the UV penetration inside the clouds), the value of $1 \mathrm{DU}$ was subtracted from the climatological correction term in the case of GOME and GOME-2 ACCO. As the geometrical top of the cloud is hundreds of metres higher than the one retrieved by FRESCO, the vertical ozone column correction between the CTH given from these algorithms and the $200 \mathrm{hPa}$ is higher than it should.

In order to restrict the variability and homogenise the ACCO in a latitude band, all ACCO measurements which result in negative TTCO or have a daily averaged standard deviation in a $2.5^{\circ}$ lat by $5^{\circ}$ long bin of more than $10 \mathrm{DU}$ or differ more than $5 \mathrm{DU}$ with the neighbouring daily binned measurements are screened out. Figure $4 \mathrm{~b}$ shows the difference between the ACCO values before (blue for GOME-2 and yellow for SCIAMACHY) and after screening out the outliers and adjusting to the $200 \mathrm{hPa}$ level (red for GOME2 and green for SCIAMACHY). The differences are generally less than $5 \mathrm{DU}$ and can reach $10 \mathrm{DU}$ for latitudes where less cloudy ozone measurements appear (in this case at southern tropics, since the ITCZ moves to northern latitudes in summer; see Fig. 3a on the right, where there are practically are no DCCs below $15^{\circ} \mathrm{S}$ ). These cases are excluded from the $<1 \%$ DCCs per latitude band criterion. Another approach for the difference between the cloud pressure level and the $200 \mathrm{hPa}$ level was used by Valks et al. (2014), assuming a constant ozone vmr of 5 ppbv between the effective cloud top and the $200 \mathrm{hPa}$ level. They concluded that the correction term is small (less than 2DU) and therefore the difference with the climatology considered negligible. After the corrections applied in GOME-2 and SCIAMACHY ACCO we can see that the agreement between them improves. The comparison of the ozone column above $200 \mathrm{hPa}$ with six ozonesonde stations from the Southern Hemisphere ADditional OZonesondes (SHADOZ) network (Ascension, Natal, Nairobi, Kuala Lumpur, Paramaribo, and Hilo) is also presented in Fig. 4b. The number of ozonesonde data for this month varies between one and four ozonesonde launches per station. The ozonesonde burst altitude resides within the stratosphere $(\sim 30 \mathrm{~km})$; therefore the above $200 \mathrm{hPa}$ ozone column from the ozonesondes had to be indirectly calculated for these stations. The ozonesonde measurements from the surface up to $200 \mathrm{hPa}$ were integrated and averaged monthly and then they were subtracted from the GOME-2 monthly-averaged total ozone measurements, deriving the ozone column above $200 \mathrm{hPa}$. The difference between the ozonesonde's ACCO and the corrected CCD $\mathrm{ACCO}$ is less than $3 \mathrm{DU}$ for these six stations.

Finally, the monthly-averaged ACCO per $2.5^{\circ}$ latitude bands from the western Pacific region $\left(70^{\circ} \mathrm{E}-170^{\circ} \mathrm{W}\right)$ is subtracted from the monthly-averaged total column $\left(2.5^{\circ}\right.$ by $5^{\circ}$ bins) of nearly cloud-free areas $(\mathrm{CF}>0.1)$, yielding the monthly TTCO.

\section{Uncertainty estimation}

This section summarises and gives a rough estimate of the main sources of uncertainty that contribute to the overall uncertainty in the retrieved TTCO. The years presented here are 2002 for GOME and 2008 for SCIAMACHY and GOME-2 ozone and cloud data. The square root of the sum of all individual quadratic uncertainties that contribute in the TCO and the ACCO results in the uncertainty of the mean TTCO. Both the uncertainty in the TCO and the uncertainty in the ACCO are supposed to be uncorrelated and follow a Gaussian distribution. The assumption that the uncertainties are Gaussian distributed might lead to underestimation while the assumption that the errors are dependent and simply add up would significantly overestimate the actual uncertainty.

The largest contribution to the WFDOAS TCO retrieval uncertainty originates from the a priori errors associated with the use of the ozone climatology and simplifying assumptions made in the derivation of effective parameters (e.g. look-up tables for albedo, altitude, and solar zenith angle, other errors like the absorbing aerosol load, the ghost vertical column, and the Ring ozone filling) (Coldewey-Egbers et al., 2005). The individually retrieved TCO has an uncertainty of 3\% (Coldewey-Egbers et al., 2005). The comparison with ground data shows an RMS difference of about $1.5 \%$ in the tropics (Weber et al., 2005). Assuming that the precision of satellite and ground data equally contribute to the RMS difference, it results in a precision of WFDOAS total ozone of about $1 \%\left(u_{\mathrm{TCO}_{\text {retrieval }}} \simeq 3 \mathrm{DU}\right.$ is the estimated average uncertainty for the individual WFDOAS TCO and $u_{\mathrm{ACCO}_{\text {retrieval }}} \simeq 2.5 \mathrm{DU}$ for the WFDOAS ACCO retrieval). The total uncertainty of the grid-box averaged total column ozone is therefore given by

$u_{\mathrm{TCO}}=\sqrt{\frac{\sum_{i=1}^{N} u_{\mathrm{TCO}}^{2}(i) \text { retrieval }}{N_{\mathrm{TCO}}}} \simeq \frac{u_{\mathrm{TCO}_{\text {retrieval }}}}{\sqrt{N_{\mathrm{TCO}}}}$, 
where $N_{\text {TCO }}$ is the number of cloud-free total ozone measurements per grid box. $u_{\mathrm{TCO}}$ is found to be generally less than 1 DU for SCIAMACHY and GOME-2 whereas it may reach $3 \mathrm{DU}$ in a few grid boxes in case of GOME (Figs. 5a, 6a and $7 \mathrm{a}$ ).

However, the greatest uncertainty contribution to the tropospheric ozone column arises from the above-cloud column calculation. For the CCD method, the above-cloud ozone column refers to pixels with CFs greater than 0.8 and CTHs greater than $7 \mathrm{~km}$ for GOME and GOME- 2 and $9 \mathrm{~km}$ for SCIAMACHY. The cloud parameter introduces the largest uncertainty contribution to ACCO. In order to calculate the possible impact of CF and CTH on the monthly-mean zonal $\mathrm{ACCO}$, the ACCO values have been calculated using the marginal values of the known uncertainties in CF and CTHs. The half of the deviation between them is then considered to be the parameter uncertainty for a given parameter change (Rahpoe et al., 2013).

The uncertainty in cloud fraction is $u_{\mathrm{CF}}$ is \pm 0.1 (Valks et al., 2015). Monthly ACCO values for cloud fractions greater than 0.7 and greater than 0.9 were calculated and uncertainty in the ACCO due to cloud fraction is then

$u_{\mathrm{ACCO}_{\mathrm{CF}}}=\frac{\left|\mathrm{ACCO}_{\mathrm{CF}>0.7}-\mathrm{ACCO}_{\mathrm{CF}>0.9}\right|}{2}$.

As seen in Figs. 5b, 6b, and 7b, the uncertainty in ACCO as a function of latitude and month for a cloud fraction perturbation of 0.1 is less than $1 \mathrm{DU}$ for GOME and SCIAMACHY and less than $2 \mathrm{DU}$ for GOME-2. This factor contributes the most to the total TTCO uncertainty.

The uncertainty in the cloud-top height, $u_{\mathrm{CTH}}$, is about $\pm 500 \mathrm{~m}$ (Lelli L., 2013). Monthly ACCO values for CTHs greater than $\mathrm{CTH}-0.5 \mathrm{~km}$ and $\mathrm{CTH}+0.5 \mathrm{~km}$ were calculated for each instrument. Equation (4) gives the mathematical formula for the uncertainty in ACCO for $\pm 500 \mathrm{~m}$ cloud -top height change:

$u_{\mathrm{ACCO}_{\mathrm{CTH}}}=\frac{\left|\mathrm{ACCO}_{\mathrm{CTH}+0.5}-\mathrm{ACCO}_{\mathrm{CTH}-0.5}\right|}{2}$.

Figures $5 \mathrm{c}, 6 \mathrm{c}$, and $7 \mathrm{c}$ show the ACCO uncertainty for a cloud-top height perturbation of $\pm 500 \mathrm{~m}$. This uncertainty is less than $0.5 \mathrm{DU}$ for all instruments.

The averaged uncertainty in the individual above-cloud ozone retrieval from WFDOAS algorithm, $u_{\mathrm{ACCO}_{(i) \text { retrieval }}}$, is $1 \%(\sim 2.5 \mathrm{DU})$. Similar to Eq. (3) for the TCO, $\frac{u_{\mathrm{ACCO}} \text { retrieval }}{\sqrt{N_{\mathrm{ACCO}}}}$, is the standard uncertainty of the monthly-mean ACCO per latitude band in the reference region of the western Pacific $\left(70^{\circ} \mathrm{E}-170^{\circ} \mathrm{W}\right)$ and $N_{\mathrm{ACCO}}$ is the number of above-cloud column ozone measurements per latitude band. The ACCO uncertainty due to cloud fraction $\left(u_{\mathrm{ACCO}_{\mathrm{CF}}}\right)$ and cloud-top height $\left(u_{\mathrm{ACCO}_{\mathrm{CTH}}}\right)$ is combined with the uncertainty from averaging in a grid box to yield the total ACCO uncertainty as follows. (a) Uncertainty in total ozone column GOME:08 2002

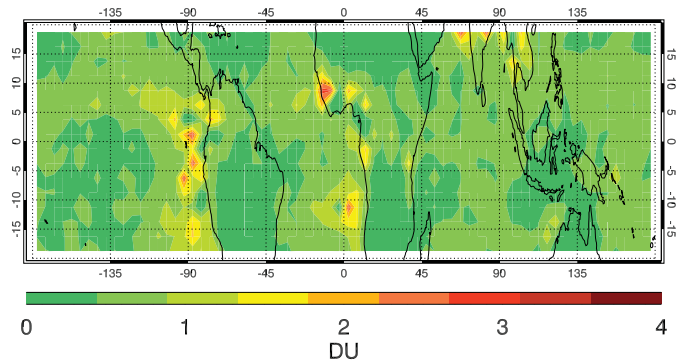

(b) Uncertainty in ACCO due to CF GOME: 2002

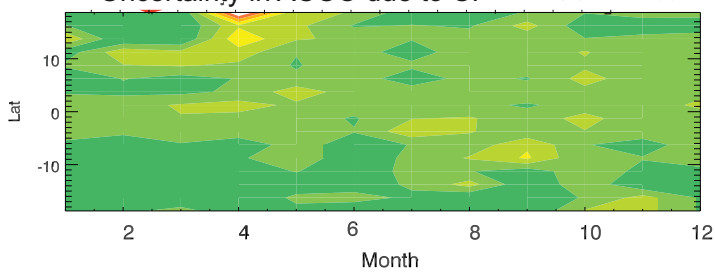

(c) Uncertainty in ACCO due to CTH GOME: 2002

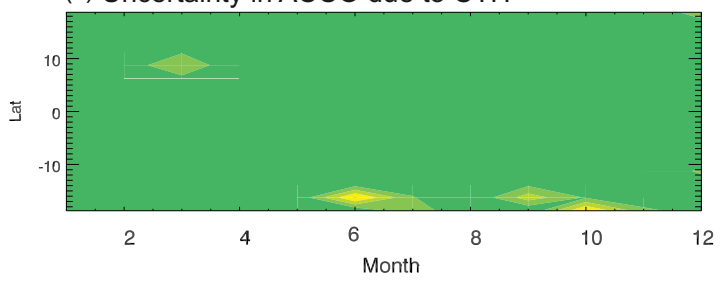

(d) Total uncertainty in the TTCO GOME: 2002

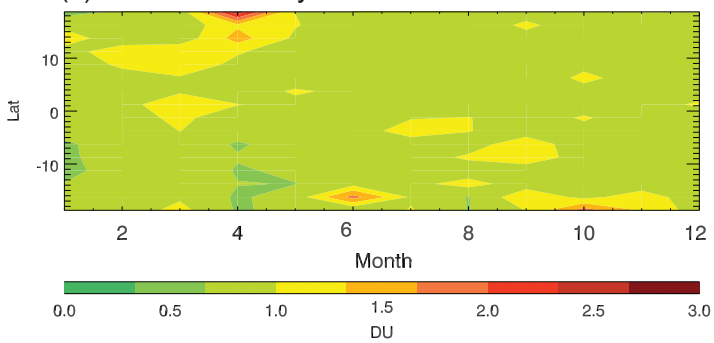

Figure 5. (a) The uncertainty in the WFDOAS TCO retrieval in August 2002 using GOME (b) the uncertainty in the monthly averaged zonal ACCO due to CF for 2002 using GOME data (c) the uncertainty in the monthly averaged zonal ACCO due to CTH for 2002 using GOME data (d) the total uncertainty in the TTCO using the CCD method and GOME WFDOAS total ozone data in 2002.

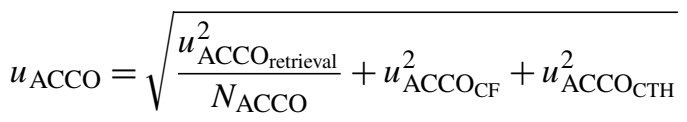

Consequently, the total ACCO uncertainty is roughly 12 DU. 
(a) Uncertainty in total ozone column SCIAMACHY: 082008

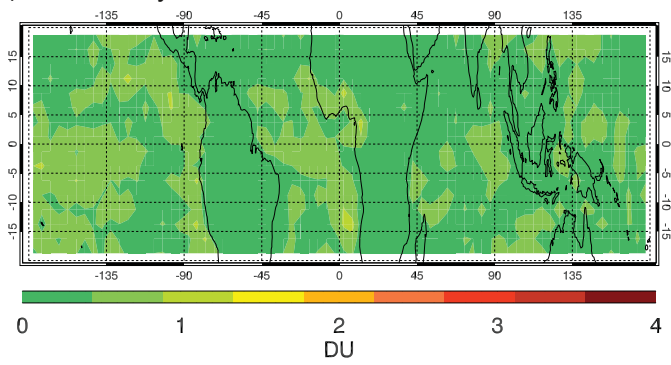

(b) Uncertainty in ACCO due to CF SCIAMACHY: 2008

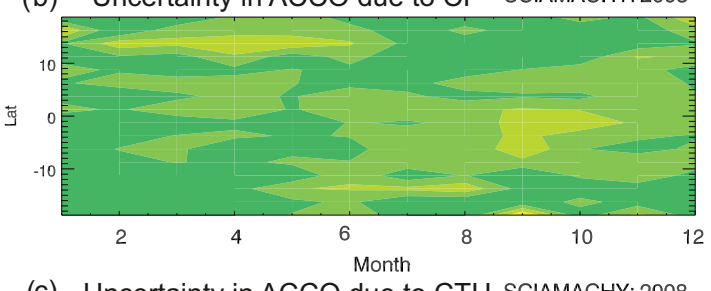

(c) Uncertainty in ACCO due to CTH SCIAMACHY: 2008

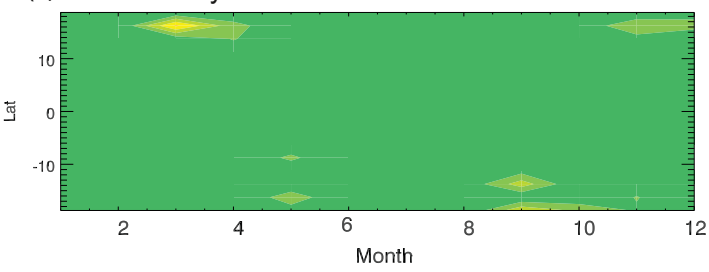

(d) Total uncertainty in the TTCO SCIAMACHY: 2008

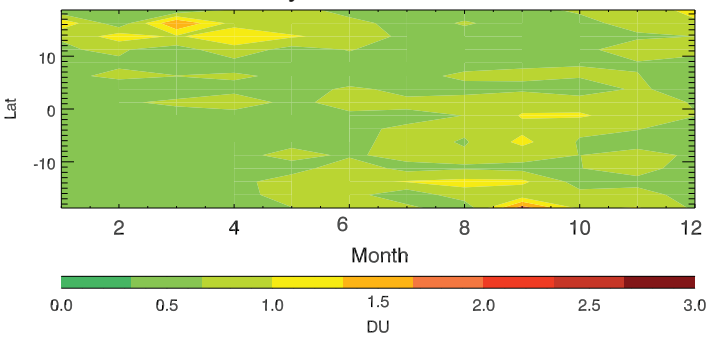

Figure 6. (a) The uncertainty in the WFDOAS TCO retrieval in August 2008 using SCIAMACHY (b) the uncertainty in the monthly averaged zonal ACCO due to CF for 2008 using SCIAMACHY data (c) the uncertainty in the monthly averaged zonal ACCO due to CTH for 2008 using SCIAMACHY data (d) the total uncertainty in the TTCO using the CCD method and SCIAMACHY WFDOAS total ozone data in 2008 .

Finally, the combined standard uncertainty of the mean tropospheric ozone column $\left(u_{\mathrm{TTCO}}\right)$ is then

$u_{\text {TTCO }}$

$=\sqrt{\frac{u_{\mathrm{TCO}_{\text {retrieval }}}^{2}}{N_{\mathrm{TCO}}}+\frac{u_{\mathrm{ACCO}}^{2}}{N_{\mathrm{ACCtrieval}}}+u_{\mathrm{ACCO}}^{2}+u_{\mathrm{ACCO}}^{2}}$.

The total uncertainty of TTCO is found to be less than 2 DU $(<10 \%)$ with GOME-2 showing the greatest values.

As shown in Figs. 5d, 6d and 7d larger uncertainties for all instruments are found in spring and autumn for both years (2002 and 2008) presented. (a) Uncertainty in total ozone column GOME-2: 082008

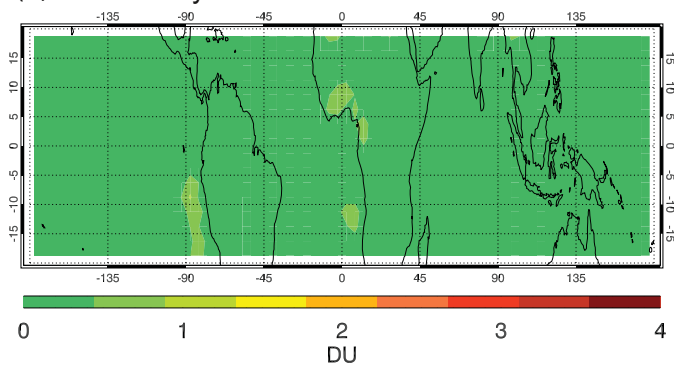

(b) Uncertainty in ACCO due to CF GOME-2: 2008

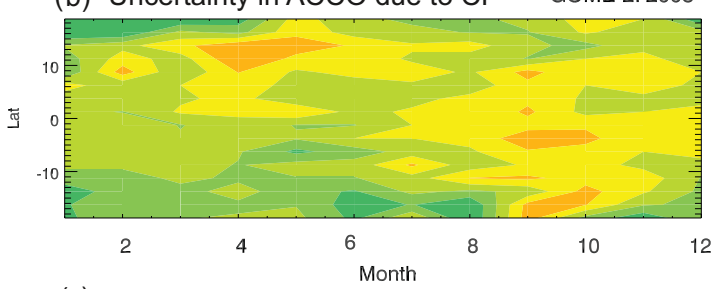

(c) Uncertainty in ACCO due to CTH GOME-2: 2008

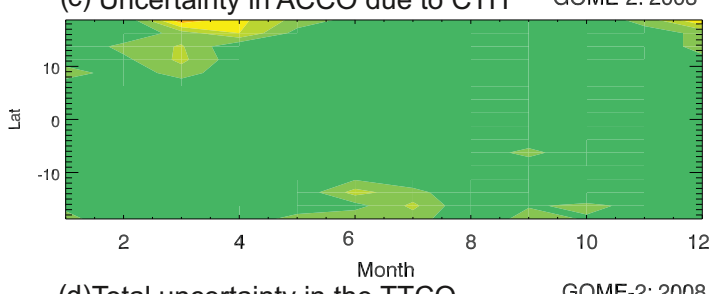

(d)Total uncertainty in the TTCO GOME-2: 2008

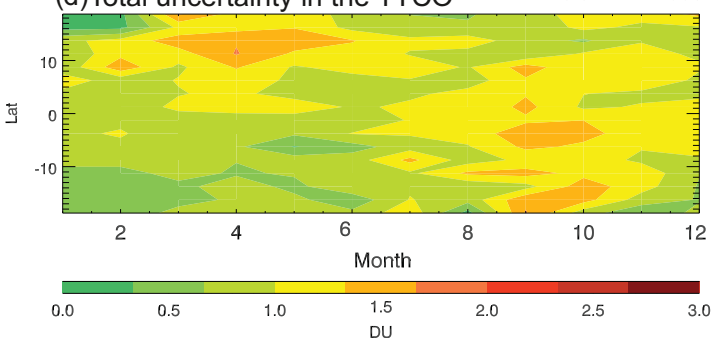

Figure 7. (a) The uncertainty in the WFDOAS TCO retrieval in August 2008 using GOME-2 (b) the uncertainty in the monthly averaged zonal ACCO due to CF for 2008 using GOME-2 data (c) the uncertainty in the monthly averaged zonal ACCO due to $\mathrm{CTH}$ for 2008 using GOME-2 data (d) the total uncertainty in the TTCO using the CCD method and GOME-2 WFDOAS total ozone data in 2008 .

\section{Results}

The CCD_IUP algorithm applied to GOME, SCIAMACHY, and GOME-2 data provides consistent results with similar patterns and range of tropospheric ozone values. The TTCO data from 1996 up to 2012 have been seasonally averaged and the tropospheric ozone column concentrations for winter, spring, summer, and autumn are presented in Fig. 8. The general wave-one pattern is well depicted for all seasons, with higher tropospheric ozone columns over the South Atlantic $(\sim 40 \mathrm{DU})$ and persistently lower values over the $\mathrm{Pa}$ cific Ocean ( 15 DU) (Diab et al., 2003; Rex et al., 2014). In winter, enhanced ozone columns $(\sim 40 \mathrm{DU})$ are noticed 
Winter: CCD tropical tropospheric ozone

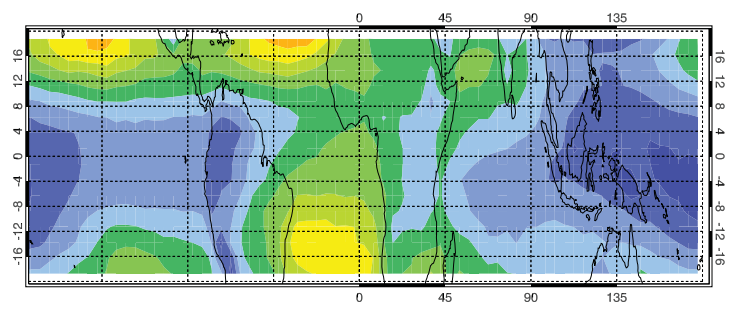

Summer: CCD tropical tropospheric ozone column

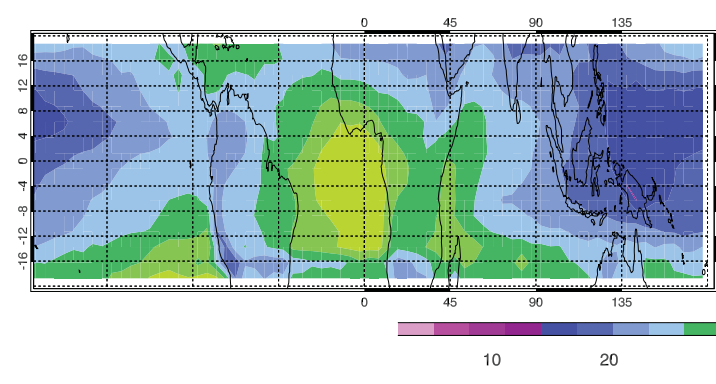

Spring: CCD tropical tropospheric ozone column

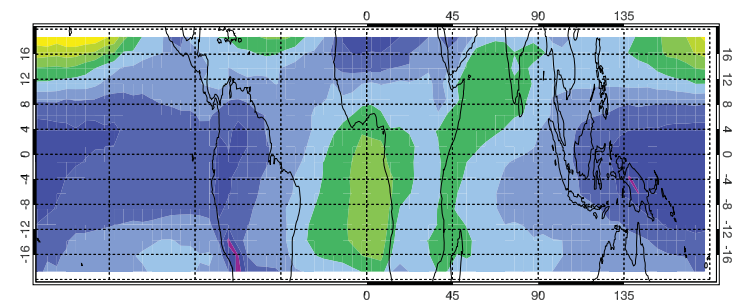

Autumn: CCD tropical tropospheric ozone column

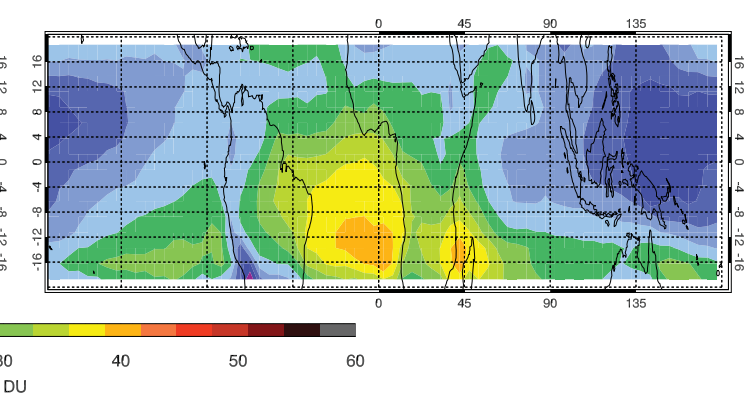

Figure 8. Seasonally averaged tropical tropospheric ozone column (TTCO) derived with the convective cloud differential (CCD) technique, From all instruments, between 1996 and 2012.

over the Atlantic and the northern tropical Pacific Ocean with a secondary maximum over the Indian Ocean. The Atlantic region is influenced by the northern biomass burning season in December-February, lightning, and large-scale transport (Martin et al., 2002; Thompson et al., 2003; Sauvage et al., 2006). The maximum over the North Pacific Ocean follows the location of the jet stream and consequently is influenced by the STE. Additionally, a large anticyclone located over the Pacific sends air from Asia towards North America during winter and spring (Oltmans et al., 2004). In spring the tropospheric ozone burden is smaller and the location of the ozone maximum is limited to the South Atlantic with noticeably smaller values ( $230 \mathrm{DU})$. In summer and autumn, the tropospheric ozone columns increase over the South Atlantic and southwestern Pacific oceans. In Autumn, the tropospheric ozone over the South Atlantic Ocean increases further (> $40 \mathrm{DU}$ ), following the southern hemispheric biomass burning season (starting in June/July and ending in October/November) (Valks et al., 2014).

Focusing on individual years, we can notice that the seasonal cycle of tropospheric ozone is well reproduced. Figure 9 shows the tropical tropospheric ozone columns for January, April, July, and October 2002 derived from GOME data. The wave-one pattern is well represented, as the higher tropospheric ozone columns appear over the central Atlantic Ocean in October (Martin et al., 2002; Sauvage et al., 2006). In order to compare the CCD_IUP results between the different satellite instruments, 2 overlapping years were selected: 2002 for GOME/SCIAMACHY comparison and 2008 for SCIAMACHY/GOME-2 comparison. Contrasting the tro- pospheric ozone columns retrieved with CCD_IUP using GOME data with the ones retrieved using SCIAMACHY data for the same months, January and April 2003 (see Fig. 9 bottom and Fig. 10 top), we conclude that the results are similar. The same pattern on tropospheric ozone for January and April 2002 can be also seen for January and April 2003. In January, the maximum ozone columns are located for both years at the South Atlantic and southwestern Pacific oceans and the minimum tropospheric ozone columns at the central-western Pacific. In April 2002 and 2003, tropospheric ozone is similar with higher values at the west coast of Africa. The comparison between SCIAMACHY and GOME-2 TTCO for January, April, July, and October 2008 is presented in Figs. 10 and 11. The tropospheric ozone burden has the expected pattern for all months and it is similar for both instruments. However, tropospheric ozone columns retrieved using GOME-2 data are apparently higher ( $\sim 8 \mathrm{DU})$ than the ones retrieved using SCIAMACHY for all months presented here.

\subsection{Validation with ozonesondes}

The accuracy of the CCD_IUP algorithm was investigated by comparisons with collocated ozonesonde measurements of tropospheric ozone columns. The ozonesonde data were taken from the SHADOZ network (Thompson et al., 2003). The closest grid box that the ozonesonde station belongs was selected for the comparison. Using a fixed grid box around the sonde station where we could apply the CCD method was also investigated but it was concluded that the 

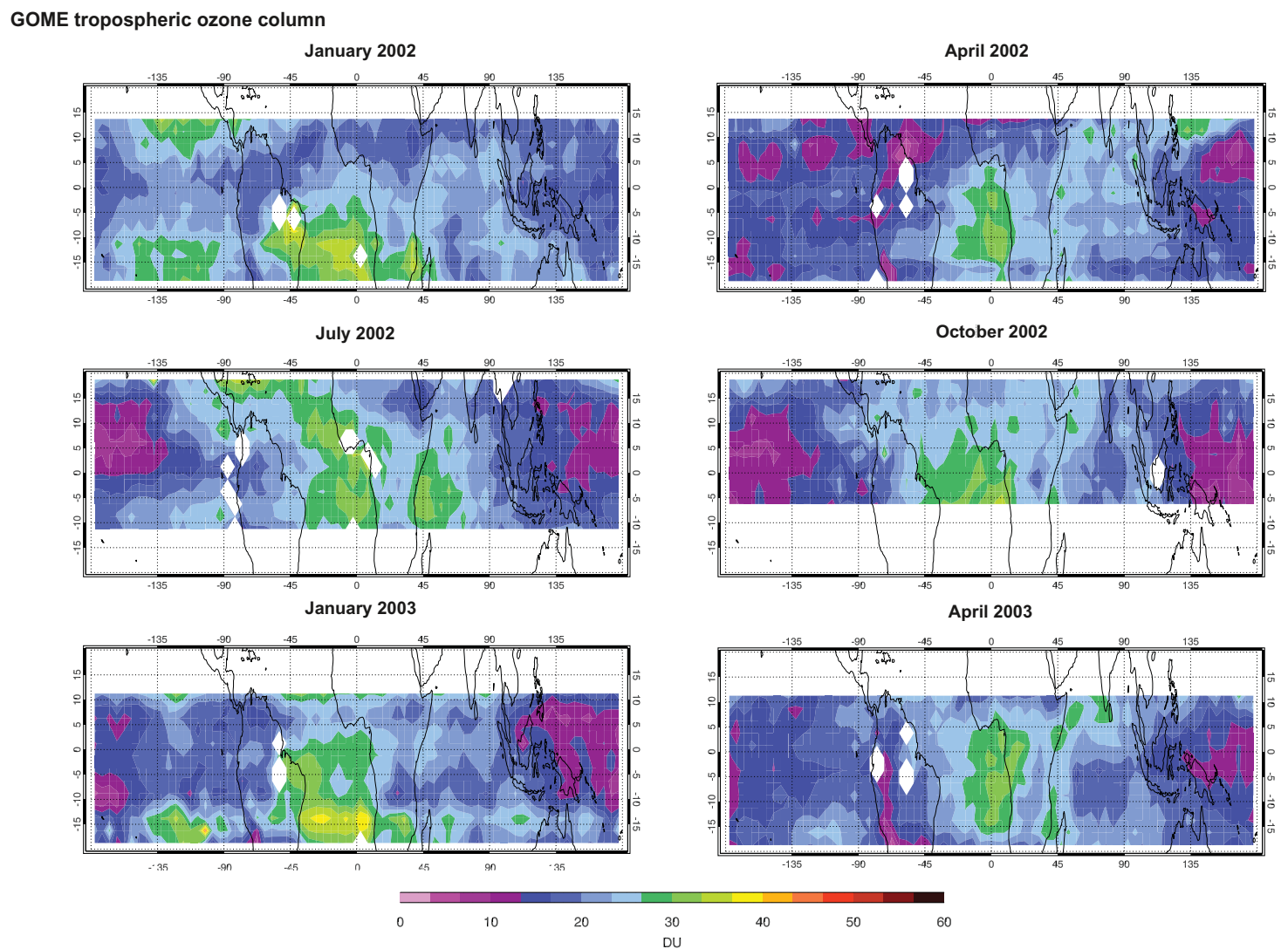

Figure 9. Tropical tropospheric ozone column (TTCO) derived with the convective cloud differential (CCD) technique for January, April, July, and October 2002 and January and April 2003 using GOME data.

statistics do not change significantly. The ozonesonde sites shown here (Figs. 12-14), starting form north to south, are (a) Hilo $\left(19.4^{\circ} \mathrm{N}, 155.4^{\circ} \mathrm{W}\right)$, (b) Paramaribo $\left(5.8^{\circ} \mathrm{N}\right.$, $\left.55.2^{\circ} \mathrm{W}\right)$, (c) Kuala Lumpur $\left(2.7^{\circ} \mathrm{S}, 101.7^{\circ} \mathrm{E}\right)$, (d) Nairobi $\left(1.4^{\circ} \mathrm{S}, 36.8^{\circ} \mathrm{E}\right)$, (e) Natal $\left(5.4^{\circ} \mathrm{S}, 35.4^{\circ} \mathrm{W}\right)$, (f) Java $\left(7.6^{\circ} \mathrm{S}\right.$, $\left.111^{\circ} \mathrm{E}\right),(\mathrm{g})$ Ascension $\left(8^{\circ} \mathrm{S}, 14.4^{\circ} \mathrm{W}\right)$, (h) Samoa $\left(14.4^{\circ} \mathrm{S}\right.$, $170.6^{\circ} \mathrm{W}$ ), and (i) Fiji $\left(18.1^{\circ} \mathrm{S}, 178.4^{\circ} \mathrm{E}\right)$. We selected the time periods of 1996-2002 for GOME, 2003-2007 for SCIAMACHY, and 2008-2012 for GOME-2 validation. For most stations, the ozonesonde measurements start in 1998 and the launches vary from one to several per month $(<5)$. The ozone profiles were integrated until $200 \mathrm{hpa}$ and the monthly mean and $1 \sigma$ standard deviation was calculated. No error bars are shown for stations with only one launch per month. Ozonesondes provide measurements along the track of the sonde, whereas tropospheric ozone from CCD covers a larger area (grid box of $2.5^{\circ}$ by $5^{\circ}$ ). Tropospheric ozone can change from 30 to $70 \mathrm{ppbv}$ within a convective cell system (Avery et al., 2010). Considering these points and the fact that ozone sonde measurements are rather sparse in time, the comparison of monthly averaged tropospheric ozone from CCD with monthly averaged tropospheric ozone from ozonesondes has some limitations.
Table 2 lists the mean GOME, SCIAMACHY, and GOME-2 TTCO as well as tropospheric ozone columns from ozonesondes at the stations mentioned above. Also presented here are the relative differences between CCD and ozonesonde, the mean bias (the difference between CCD and ozonesondes), the RMS deviation (the standard deviation of the differences between CCD and ozonesondes), and the correlation coefficient $(R)$ between the CCD and ozonesonde time series. The comparison for all these ozonesonde stations shows that the bias is less than 5.6 DU, the mean relative differences range between 8 and $31 \%$, the RMS is between 4 and $10 \mathrm{DU}$, and the correlation coefficient $R$ ranges between 0.0 (Kuala Lumpur/GOME-2) and 0.9 (Ascension/GOME2). Comparing the CCD_IUP results for each instrument with ozonesondes, we conclude that SCIAMACHY TTCO have the smallest relative differences $(8-19 \%)$, bias $(-3.7 \mathrm{DU})$, and RMS (2.6-8.4 DU) with the ozonesondes. Additionally, in more than half of the stations (five over nine) there is a strong correlation $(R>0.6)$. GOME CCD_IUP results, however, have generally small biases with the ozonesondes with the exception of Hilo, where the bias is 4.1 DU. The RMS differences are less than 7DU (with the exception of Hilo, where the RMS difference is up to 10DU) and the correlation is strong only at three over nine stations used for the 
SCIAMACHY tropospheric ozone column

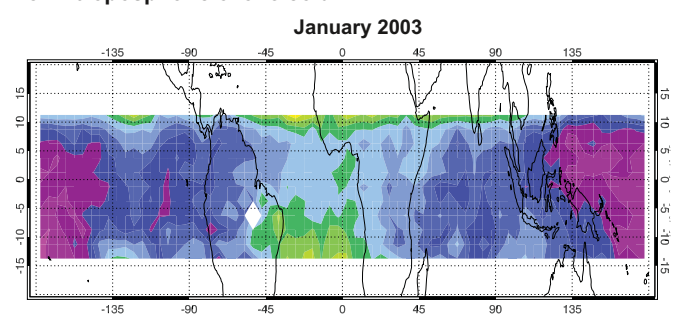

January 2008

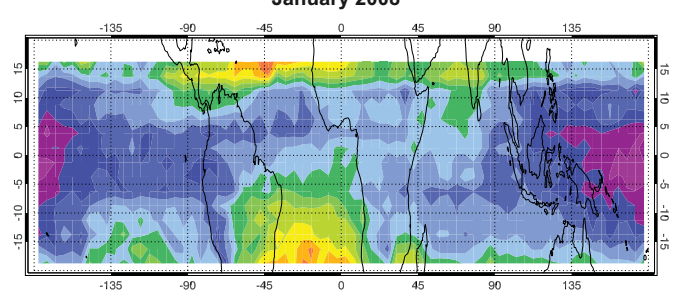

July 2008

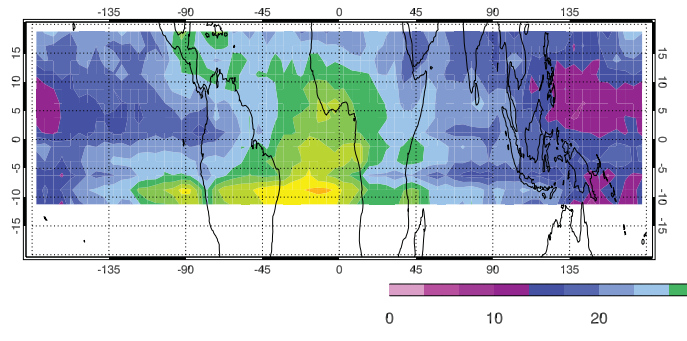

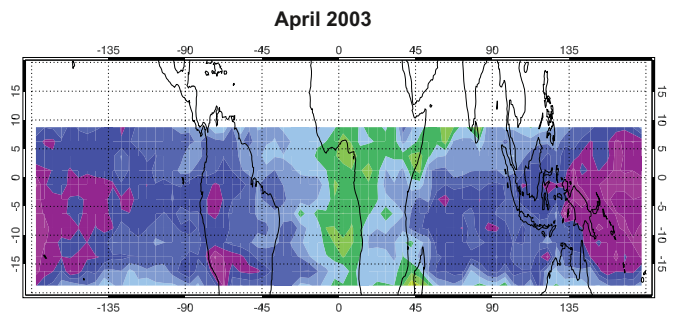

April 2008
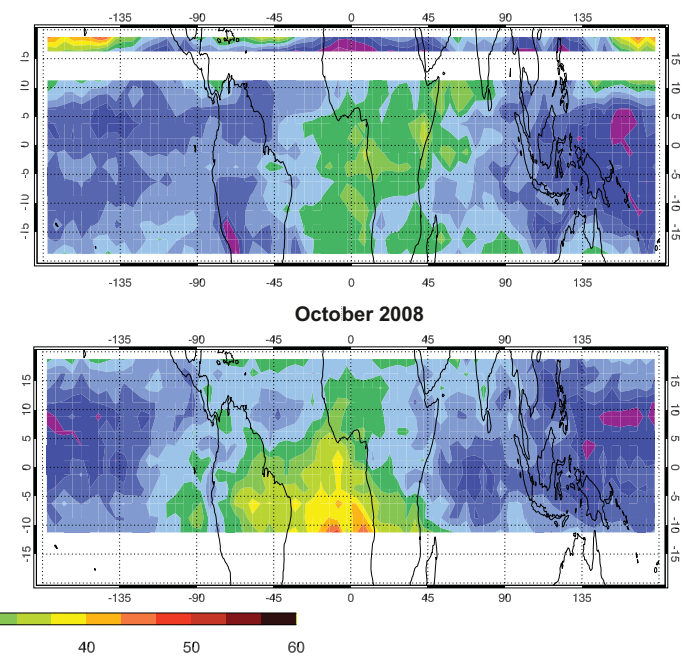

Figure 10. Tropical tropospheric ozone column (TTCO) derived with the convective cloud differential (CCD) technique for January and April 2003 and January, April, July, and October 2008 using SCIAMACHY data.

GOME-2 tropospheric ozone column
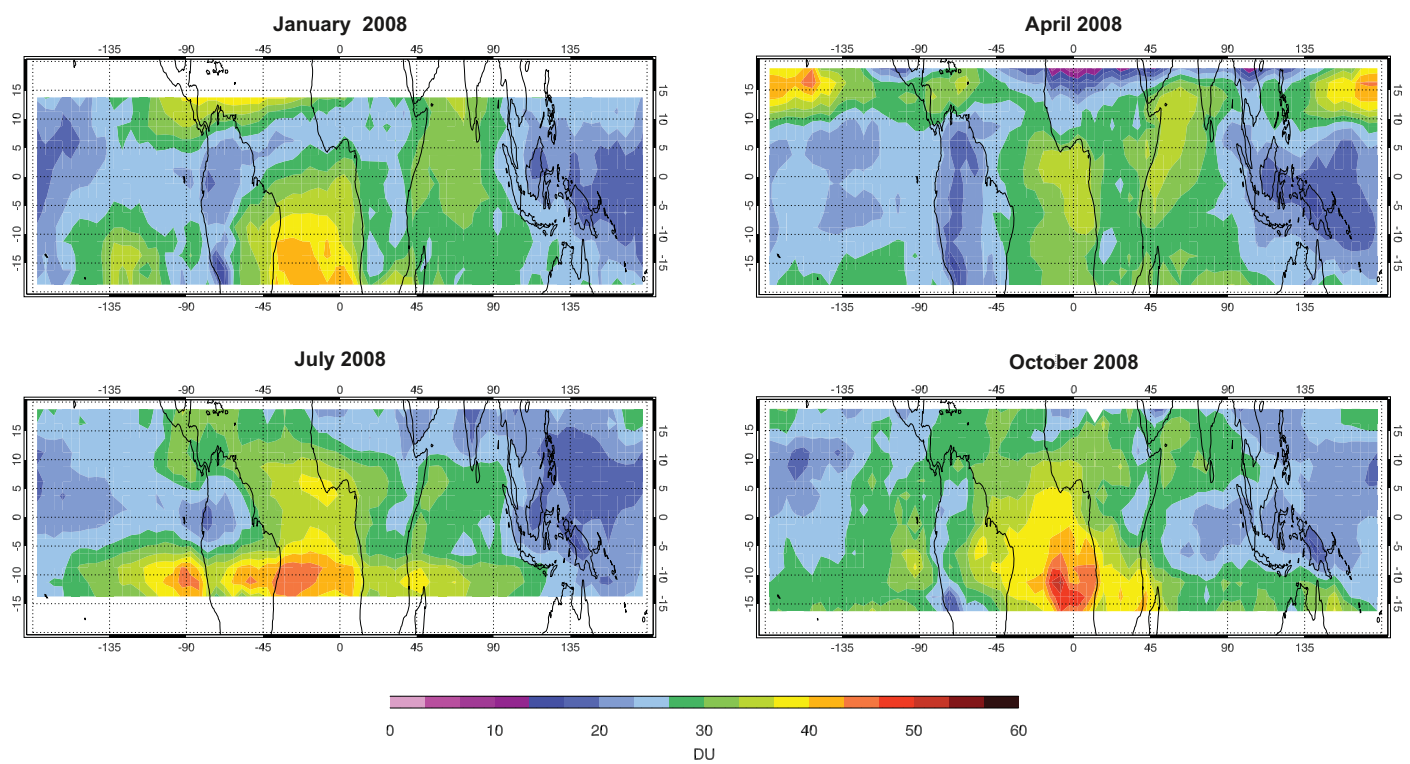

Figure 11. Tropical tropospheric ozone column (TTCO) derived with the convective cloud differential (CCD) technique for January, April, July, and October 2008 using GOME-2 data. 
Table 2. Statistical comparison between GOME, SCIAMACHY, and GOME-2 TTCO with ozonesondes for nine SHADOZ sites. Information presented here are the ozonesonde site, the mean TTCO for GOME/SCIAMACHY and for ozonesondes, the relative difference, the bias, and the RMS difference between CCD TTCO and sondes and finally the correlation coefficient.

\begin{tabular}{|c|c|c|c|c|c|c|}
\hline Site (1996-2002) & GOME TTCO (DU) & SONDES TTCO (DU) & Relative difference & BIAS (DU) & RMS (DU) & $R$ \\
\hline Hilo $\left(19.4^{\circ} \mathrm{N}, 155.4^{\circ} \mathrm{W}\right)$ & 30.2 & 26.2 & $24 \%$ & 4.1 & 10.2 & 0.6 \\
\hline Paramaribo $\left(5.8^{\circ} \mathrm{N}, 55.2^{\circ} \mathrm{W}\right)$ & 23.4 & 24.4 & $14 \%$ & -1.0 & 3.8 & 0.5 \\
\hline Kuala Lumpur $\left(2.7^{\circ} \mathrm{N}, 101.7^{\circ} \mathrm{E}\right)$ & 19.4 & 19.8 & $16 \%$ & -0.4 & 4.6 & 0.2 \\
\hline Nairobi $\left(1.3^{\circ} \mathrm{S}, 36.8^{\circ} \mathrm{E}\right)$ & 24.6 & 23.5 & $12 \%$ & 1.1 & 3.9 & 0.6 \\
\hline Natal $\left(5.4^{\circ} \mathrm{S}, 35.4^{\circ} \mathrm{W}\right)$ & 29.4 & 28.0 & $15 \%$ & 1.4 & 5.5 & 0.7 \\
\hline Java $\left(7.6^{\circ} \mathrm{S}, 111^{\circ} \mathrm{E}\right)$ & 19.2 & 19.6 & $21 \%$ & -0.4 & 5.2 & 0.1 \\
\hline Ascension $\left(8^{\circ} \mathrm{S}, 14.4^{\circ} \mathrm{W}\right)$ & 31.6 & 32.4 & $15 \%$ & -0.8 & 6.6 & 0.4 \\
\hline Samoa $\left(14.4^{\circ} \mathrm{S}, 170.6^{\circ} \mathrm{W}\right)$ & 23.4 & 24.4 & $14 \%$ & -1.0 & 3.8 & 0.5 \\
\hline Fiji $\left(18.1^{\circ} \mathrm{S}, 178.4^{\circ} \mathrm{E}\right)$ & 20.7 & 18.6 & $28 \%$ & 2.1 & 6.0 & 0.5 \\
\hline Site (2003-2007) & SCIAMACHY TTCO (DU) & SONDES TTCO (DU) & Relative difference & BIAS (DU) & RMS (DU) & $R$ \\
\hline Hilo $\left(19.4^{\circ} \mathrm{N}, 155.4^{\circ} \mathrm{W}\right)$ & 25.0 & 27.6 & $26 \%$ & -2.6 & 8.4 & 0.6 \\
\hline Paramaribo $\left(5.8^{\circ} \mathrm{N}, 55.2^{\circ} \mathrm{W}\right)$ & 20.5 & 22.3 & $23 \%$ & -1.8 & 7.0 & 0.4 \\
\hline Kuala Lumpur $\left(2.7^{\circ} \mathrm{N}, 101.7^{\circ} \mathrm{E}\right)$ & 19.1 & 22.1 & $18 \%$ & -3.0 & 5.0 & 0.3 \\
\hline Nairobi $\left(1.3^{\circ} \mathrm{S}, 36.8^{\circ} \mathrm{E}\right)$ & 23.8 & 23.6 & $8 \%$ & 0.2 & 2.6 & 0.7 \\
\hline Natal $\left(5.4^{\circ} \mathrm{S}, 35.4^{\circ} \mathrm{W}\right)$ & 26.0 & 28.0 & $14 \%$ & -2.0 & 4.9 & 0.8 \\
\hline Java $\left(7.6^{\circ} \mathrm{S}, 111^{\circ} \mathrm{E}\right)$ & 17.6 & 21.3 & $25 \%$ & -3.7 & 5.8 & 0.6 \\
\hline Ascension $\left(8^{\circ} \mathrm{S}, 14.4^{\circ} \mathrm{W}\right)$ & 30.4 & 33.2 & $16 \%$ & -2.8 & 6.7 & 0.7 \\
\hline Samoa $\left(14.4^{\circ} \mathrm{S}, 170.6^{\circ} \mathrm{W}\right)$ & 20.5 & 22.3 & $23 \%$ & -1.8 & 6.7 & 0.4 \\
\hline Fiji $\left(18.1^{\circ} \mathrm{S}, 178.4^{\circ} \mathrm{E}\right)$ & 15.2 & 17.6 & $29 \%$ & -2.4 & 6.3 & 0.1 \\
\hline Site (2008-2012) & GOME-2 TTCO (DU) & SONDES TTCO (DU) & Relative difference & BIAS (DU) & RMS (DU) & $R$ \\
\hline Hilo $\left(19.4^{\circ} \mathrm{N}, 155.4^{\circ} \mathrm{W}\right)$ & 32.9 & 27.6 & $19 \%$ & 5.3 & 9.0 & 0.6 \\
\hline Paramaribo $\left(5.8^{\circ} \mathrm{N}, 55.2^{\circ} \mathrm{W}\right)$ & 29.5 & 22.7 & $31 \%$ & 6.8 & 9.2 & 0.4 \\
\hline Kuala Lumpur $\left(2.7^{\circ} \mathrm{N}, 101.7^{\circ} \mathrm{E}\right)$ & 23.7 & 21.1 & $20 \%$ & 2.6 & 5.4 & 0.0 \\
\hline Nairobi $\left(1.3^{\circ} \mathrm{S}, 36.8^{\circ} \mathrm{E}\right)$ & 28.9 & 24.1 & $20 \%$ & 4.8 & 6.1 & 0.4 \\
\hline Natal $\left(5.4^{\circ} \mathrm{S}, 35.4^{\circ} \mathrm{W}\right)$ & 33.0 & 29.1 & $17 \%$ & 3.9 & 5.7 & 0.8 \\
\hline Java $\left(7.6^{\circ} \mathrm{S}, 111^{\circ} \mathrm{E}\right)$ & 23.4 & 21.4 & $18 \%$ & 2.0 & 4.8 & 0.5 \\
\hline Ascension $\left(8^{\circ} \mathrm{S}, 14.4^{\circ} \mathrm{W}\right)$ & 36.2 & 31.5 & $16 \%$ & 4.6 & 5.5 & 0.9 \\
\hline Samoa $\left(14.4^{\circ} \mathrm{S}, 170.6^{\circ} \mathrm{W}\right)$ & 24.7 & 19.1 & $30 \%$ & 5.6 & 6.8 & 0.6 \\
\hline Fiji $\left(18.1^{\circ} \mathrm{S}, 178.4^{\circ} \mathrm{E}\right)$ & 24.9 & 20.7 & $29 \%$ & 4.2 & 6.8 & 0.3 \\
\hline
\end{tabular}

comparison. GOME-2 CCD_IUP results compared with the nine ozonesonde stations show a persistently positive bias (2-5.6 DU). The RMS differences are greater (4.8-9.2 DU) among the three instruments and the correlation is strong at four stations.

Figures 12-14 present the tropospheric ozone time series from the CCD_IUP method plotted with collocated ozonesondes measurements (until $200 \mathrm{hPa}$ ) for the aforementioned stations. In more detail, Figure 14a shows the comparison of tropospheric ozone column with ozonesondes in Ascension island, which is located in the South Atlantic. The mean tropospheric ozone columns are the highest among all the stations ( $\sim 33 \mathrm{DU})$. The seasonal cycle is strong, with maximum in autumn (biomass burning season) and minimum in late spring, when the ITCZ passes over the island and the wet season begins. Similar seasonal pattern with slightly smaller mean values $(\sim 29 \mathrm{DU})$ can be seen in Natal (Fig. 13b), which is located $3400 \mathrm{~km}$ northwest of Ascension. The same seasonal pattern is noticed in Paramaribo (Fig. 12b), showing a distinct seasonal cycle (minimum at spring; maximum at autumn) but with even smaller mean tropospheric ozone values $(\sim 24 \mathrm{DU})$. The correlation with ozonesondes in these stations is highest $(R=0.4-0.9)$, mainly due to the fact that they have a distinct seasonal cycle. In contrast, Nairobi station (Fig. 13a; central-eastern Africa) shows even lower mean tropospheric ozone abundance $(\sim 25 \mathrm{DU})$ and very small seasonal variations. The reduced seasonal cycle can be explained by the location of Nairobi away from the southwestern continental outflow due to the Harmattan winds.

The CCD_IUP time series for the Indian Ocean stations such as Kuala Lumpur and Java (Figs. 12c and 13c) show very low mean tropospheric ozone values $(\sim 20 \mathrm{DU})$. The ozone abundance gets even lower $(<10 \mathrm{DU})$ during summer (particularly in the case of SCIAMACHY and GOME retrievals) when the monsoon season is active and the ITCZ moves northwards. The southeastern trade winds of the Southern Hemisphere crossing the Equator are deflected eastwards in the Northern Hemisphere due to the Coriolis effect, yielding into the $\mathrm{C}$-shape monsoon winds blowing from the southwestern direction in the lower troposphere (Loschnigg and Webster, 2000; Yonemura et al., 2002). As 

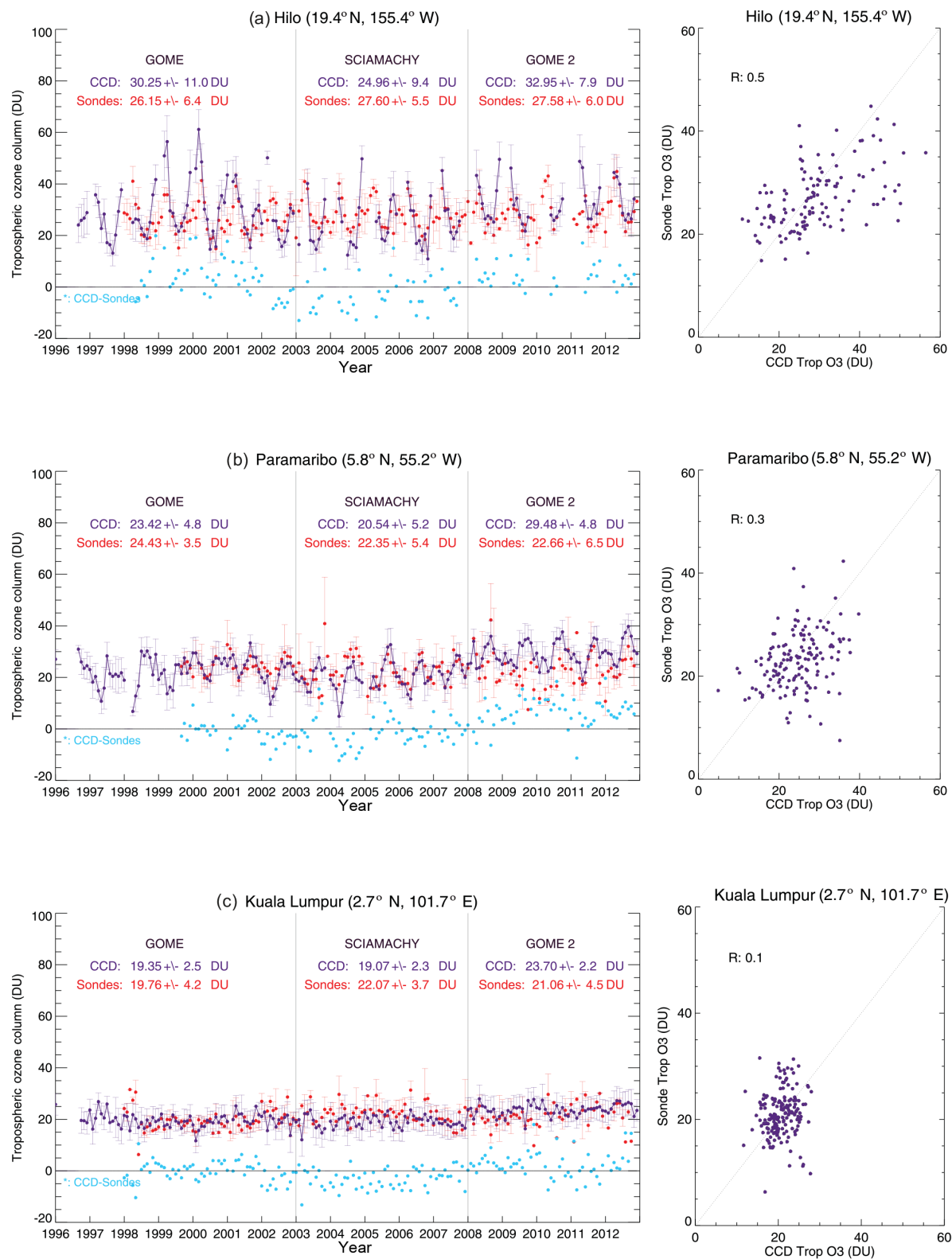

Figure 12. Time series of monthly-mean CCD tropospheric ozone columns and collocated monthly-mean SHADOZ ozonesonde TTCO in Hilo, Paramaribo, and Kuala Lumpur (from top to bottom). The red lines give the integrated ozone column from sonde ozone up to the fixed level of $200 \mathrm{hPa}$ (roughly $12 \mathrm{~km}$ ). The blue lines are (i) GOME-1 CCD ozone columns (1996-2002), (ii) SCIAMACHY CCD ozone columns (2003-2007), and (iii) GOME-2 CCD ozone columns (2008-2012). Error bars indicate the standard deviation of the monthly mean. No error bars are shown for months with only one ozonesonde launch available. The difference between CCD and ozonesondes is plotted with light blue colour.

a result, clean ozone air reaches the Indonesian-Malaysian Peninsula. The opposite circulation takes place in winter, where the gradient is turning from south to north bringing polluted continental air to both sites. Additionally, ozone peaks can be seen at Java station (Watukosek) during the pre-midwinter months of 1997, 2002, 2004, 2006, and 2009 (October-January) due to El Niño conditions (Ziemke et al., 2010). El Niño is linked to changes in the convection pat- tern (less clouds over Indonesian region) and increase of biomass burning (Valks et al., 2014). Generally, the correlation with the Indian Ocean stations is weak $(0<R<0.6)$ since tropospheric ozone is low, the seasonal cycle is weak or even nonexistent while the bias $(<3.7 \mathrm{DU})$ and the RMS errors are small $(<6 \mathrm{DU})$, indicating that the CCD TTCO can be considered as having acceptable agreement with the ozonesondes. 

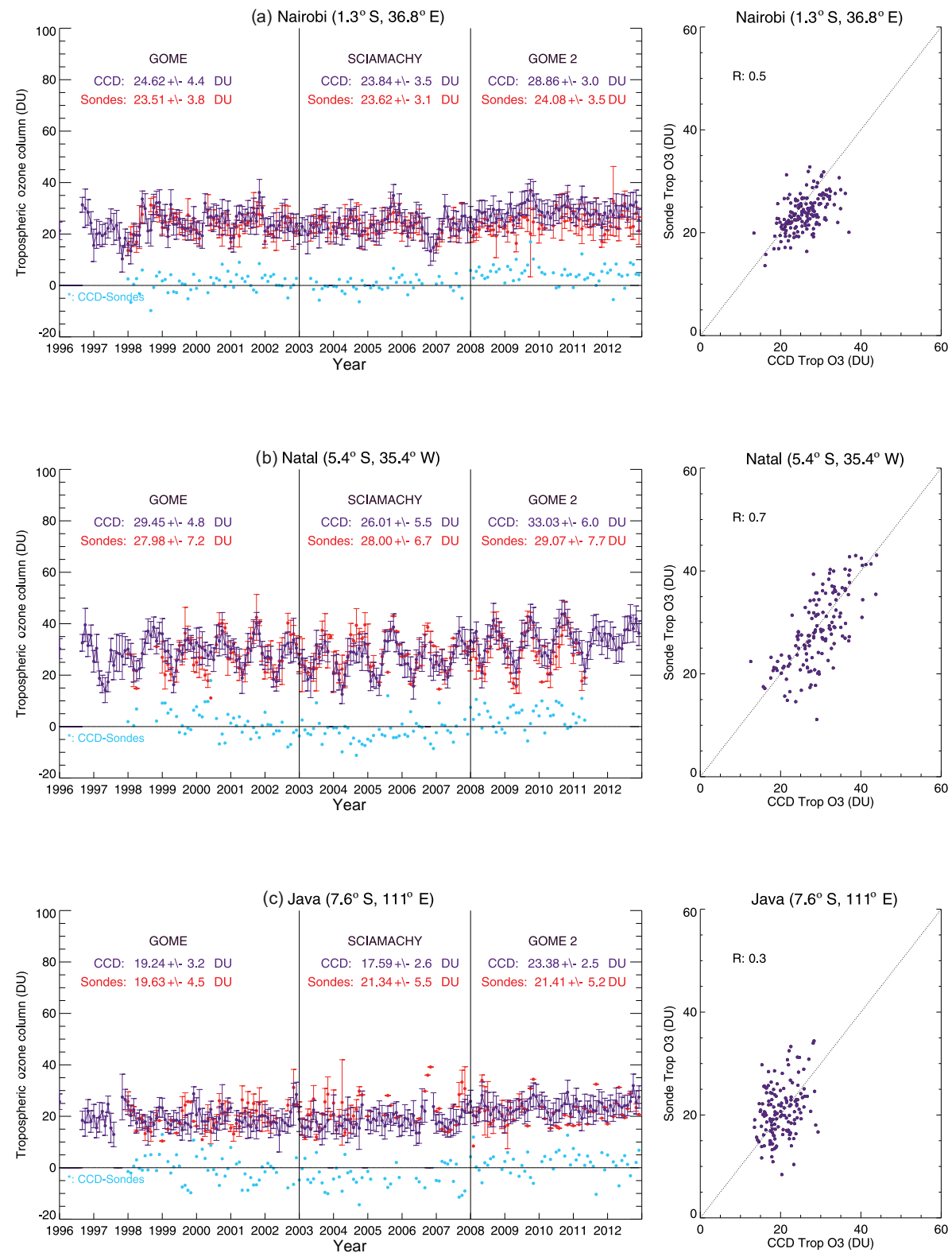

Figure 13. Time series of monthly-mean CCD tropospheric ozone columns and collocated monthly-mean SHADOZ ozonesonde TTCO in Nairobi, Natal, and Java (from top to bottom). The red lines give the integrated ozone column from sonde ozone up to the fixed level of $200 \mathrm{hPa}$ (roughly $12 \mathrm{~km}$ ). The blue lines are: (i) GOME-1 CCD ozone columns (1996-2002), (ii) SCIAMACHY CCD ozone columns (2003-2007), and (iii) GOME-2 CCD ozone columns (2008-2012). Error bars indicate the standard deviation of the monthly mean. No error bars are shown for months with only one ozonesonde launch available. The difference between CCD and ozonesondes is plotted with light blue colour.

At the Pacific Ocean site of Hilo (Fig. 12a) tropospheric ozone is among the highest ( $\sim 29 \mathrm{DU})$. Hilo is located in the northern tropics, at a location where the jet stream passes during winter months. Consequently, Hilo is influenced by stratospheric intrusions via tropopause foldings. Additionally, a large anticyclone located over the Pacific sends air from Asia towards North America during winter and spring (Oltmans et al., 2004). However, the movement of the ITCZ at southern latitudes in boreal winter months causes less clouds over that region and as a result insufficient data to retrieve ACCO and consequently TTCO. The opposite picture can be noticed in Fiji (Fig. 14c) where higher ozone columns appear during boreal summer months. Both stations are located near the southern and northern boundary of the tropical region. As a result, the ACCO measurements are considered to be statistically doubtful and no TTCO is re- 

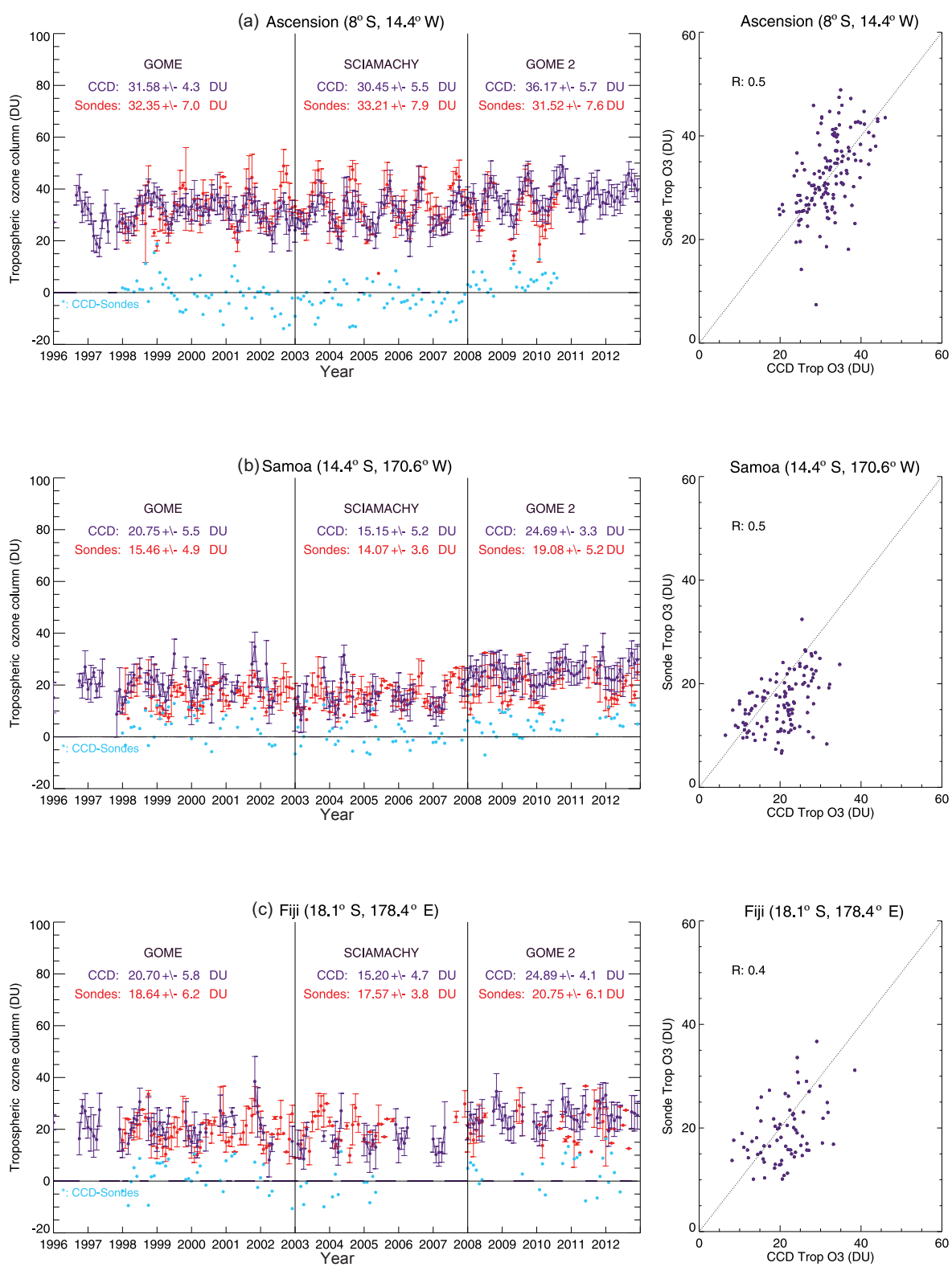

Figure 14. Time series of monthly-mean CCD tropospheric ozone columns and collocated monthly-mean SHADOZ ozonesonde TTCO in Ascension, Samoa, and Fiji (from top to bottom). The red lines give the integrated ozone column from sonde ozone up to the fixed level of $200 \mathrm{hPa}$ (roughly $12 \mathrm{~km}$ ). The blue lines are: (i) GOME-1 CCD ozone columns (1996-2002), (ii) SCIAMACHY CCD ozone columns (2003-2007), and (iii) GOME-2 CCD ozone columns (2008-2012). Error bars indicate the standard deviation of the monthly mean. No error bars are shown for months with only one ozonesonde launch available. The difference between CCD and ozonesondes is plotted with light blue colour.

trieved in these cases. Finally, Fig. 14b presents the tropospheric ozone at Samoa island, which ranges around $21 \mathrm{DU}$ with slightly higher values in autumn. The comparison of CCD_IUP results and ozonesondes at Samoa shows that CCD_IUP mainly overestimates the retrieved tropospheric ozone for GOME and GOME-2.

\subsection{Comparison with limb/nadir matching tropospheric ozone columns}

Tropospheric ozone columns from LNM observations of SCIAMACHY are available (Ebojie et al., 2014). The monthly-mean tropospheric ozone columns retrieved with the LNM technique have in general errors of less than $6 \mathrm{DU}$, and the comparison with collocated and integrated ozonesonde profiles up to the tropopause shows agreement 
(a) SCIAMACHY CCD tropospheric ozone column: 082008

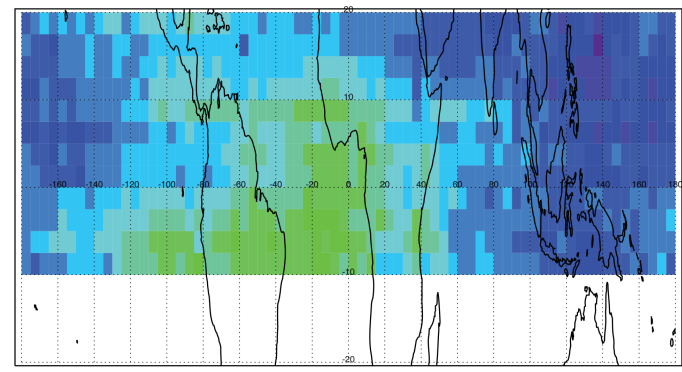

(b)

SCIAMACHY limb-nadir TCCO: 082008
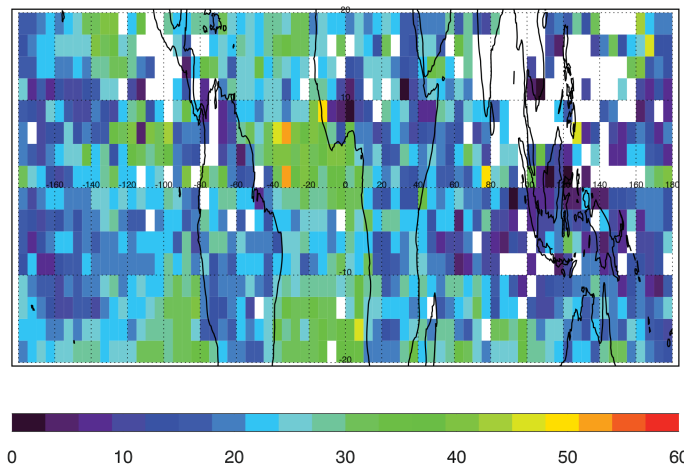

(c) SCIAMACHY CCD minus LNM tropospheric ozone column: 082008

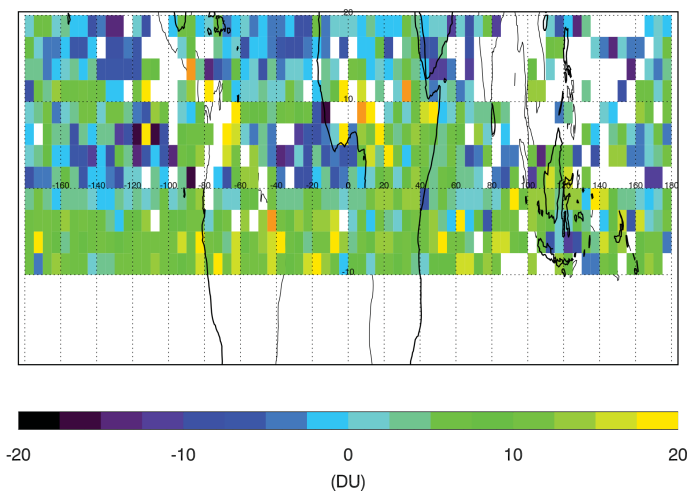

Figure 15. (a) Tropical tropospheric ozone column from CCD SCIAMACHY for August 2008. (b) SCIAMACHY tropical tropospheric ozone column from limb/nadir matching technique up to $200 \mathrm{hPa}$ for August 2008. (c) Difference between CCD and LNM SCIAMACHY data in August 2008.

within 2-5 DU and mean relative differences of $6-25 \%$ in the tropics. (Ebojie et al., 2014). The comparison with other satellite instruments such as TES and OMI/MLS generally shows similar features; nevertheless, there are obvious differences in regional patterns mainly due to instrumental differences, differences in the vertical resolutions, and overpass times. In order to make the comparison between the tropospheric ozone columns from CCD and LNM more realistic, the $\mathrm{CCD}$ data have been gridded with the same $2.5^{\circ} \times 5^{\circ}$ grid and the ozone amount between the tropopause and $200 \mathrm{hPa}$ has been subtracted from the LNM ozone columns using the Fortuin and Kelder (1998) climatology.

Figure 15 shows the TTCO from CCD (top) and LNM (middle) from SCIAMACHY in August 2008. Higher ozone columns are located over the central Atlantic Ocean while the lowest is over the Pacific Ocean. However, LNM tropospheric ozone data are sparse between 70 and $160^{\circ} \mathrm{E}$ and over southern Central America. It is also apparent that the LNM tropospheric ozone columns appear somewhat noisier with elevated ozone columns (40 DU) appearing for example over the Pacific Ocean, where the neighbouring grid boxes are around 15 DU.

Figure 16 presents the comparison between CCD and LNM tropical tropospheric ozone columns for the years 2003-2011. Figure 16a shows the mean tropospheric ozone column bias (CCD minus LNM TTCO) ranging between $\pm 5 \mathrm{DU}$, with the exception of southeastern America and central Africa where it reaches $10 \mathrm{DU}$. The bias is mainly positive over land and negative at the borders of the tropical belt, the central Pacific Ocean, and Atlantic Ocean. The RMS error (Fig. 16b) is generally less than $10 \mathrm{DU}$, which is within the range of the comparison of CCD_IUP with the ozonesondes. The mean absolute bias is less than $3 \mathrm{DU}$ and the mean absolute relative difference is $\sim 12 \%$. Finally, the correlation (Fig. 16c) is moderate to low with the exception of the areas that present high ozone columns. There are also some anticorrelated grid boxes which are located in areas where LNM data are usually sparse. The bias between LNM and CCD tropospheric ozone could be partly explained by the overestimation of limb V2.9 ozone profiles used for LNM. The comparison with ozonesondes in the tropics shows a positive bias of 5 to $10 \mathrm{DU}$ (Jia et al., 2015). The position of positive and negative biases seems to agree well with the ones for the limb profiles. For the newest limb version 3.0, the seasonal variations in the time series are in better agreement with those from sonde data at most tropical stations (Jia et al., 2015). Limb V3.0 is planned to be used in the newest LNM tropospheric ozone dataset and an improvement in the agreement between the two methods is expected.

\section{Conclusions}

Monthly averaged tropospheric ozone columns have been calculated on a $2.5^{\circ}$ latitude by $5^{\circ}$ longitude grid between $20^{\circ} \mathrm{S}$ and $20^{\circ} \mathrm{N}$ using the CCD method from 1996 to 2012 for GOME/ERS-2, SCIAMACHY/ENVISAT, and GOME2/MetOp-A data. The method indicates that the retrieved ACCO provides a reasonable approximation of the stratospheric ozone columns despite the assumptions and corrections done in the ACCO calculation, although there are limitations due to cases of limited cloudy data in some latitude bands as a result of the ITCZ seasonal migration. The comparison with nine SHADOZ ozonesonde sites shows biases 
(a) CCD-LNM tropospheric ozone column mean bias (DU)

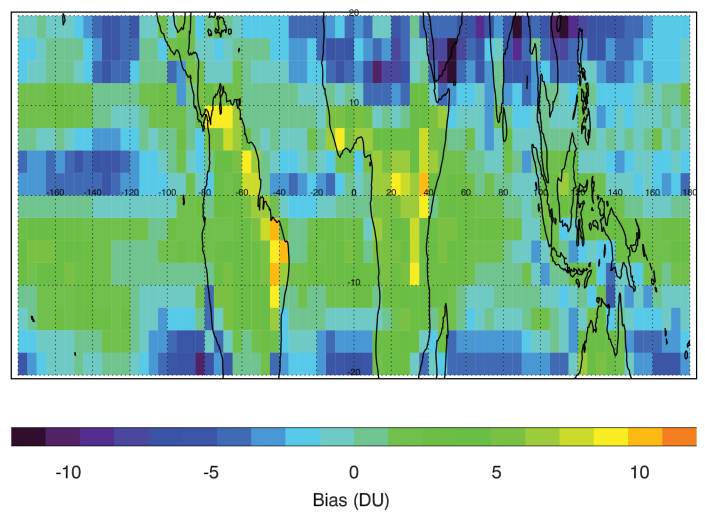

(b) CCD-LNM tropospheric ozone column RMS (DU)

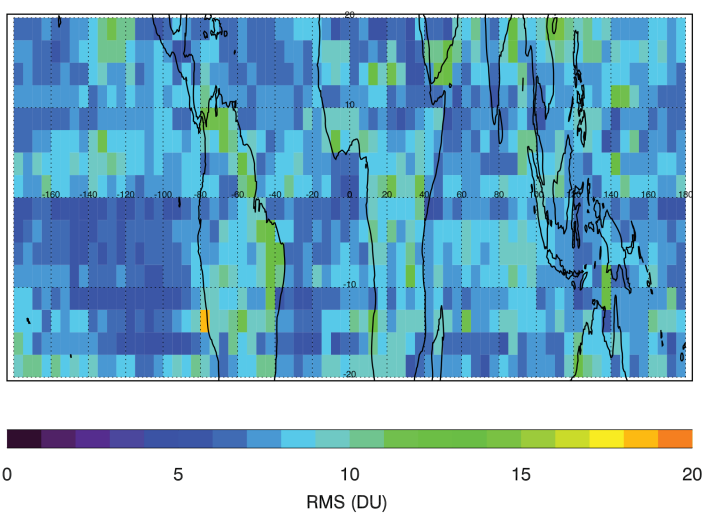

(c) Correlation between CCD and LNM tropical tropospheric ozone column

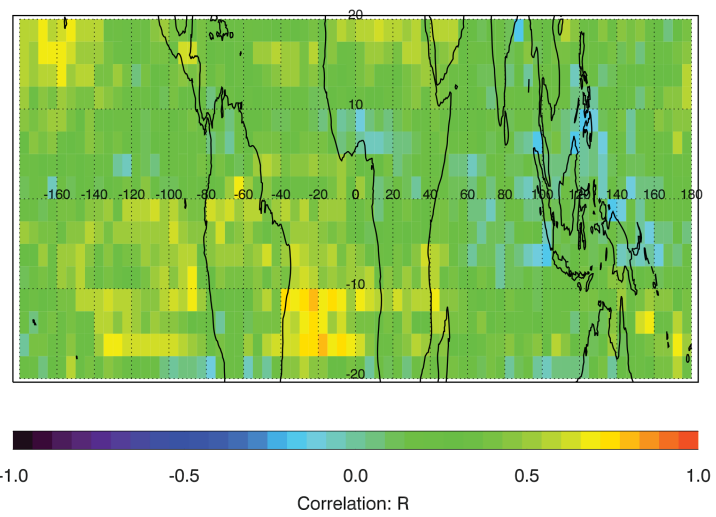

Figure 16. (a) Mean bias between CCD and LNM for the years 2003 until 2011. (b) Correlation $(R)$ between CCD and LNM SCIAMACHY tropospheric ozone for the years 2003 until 2011.

less than 5.6 DU, mean relative differences between 8 and $31 \%$, and RMS error is between 4 and $10 \mathrm{DU}$. The comparison with limb/nadir-matching observations from SCIAMACHY show good agreement (mean absolute bias $<5$ DU and the mean absolute relative difference $\sim 12 \%$ ). Further optimisation of the WFDOAS data (use of the same algorithm for cloud properties for all satellite data) and extension to GOME-2/MetOp-B is planned in order to improve the consistency between satellite datasets for long-term trend and variability studies. It is planned to harmonise the three separate datasets (GOME/SCIAMACHY/GOME-2) into one consistent merged dataset, covering the time span between 1995 and present. In summary, this unique 17-year tropical tropospheric ozone dataset provides valuable information about the tropospheric ozone distribution. These long-term tropospheric ozone time series can be used in climatological and tropospheric ozone trend studies.

\section{Data availability}

The WFDOAS Total Ozone Algorithm has been developed (Coldewey-Egbers et al., 2005) and continuously improved (Weber et al., 2007) at the Institute of Environmental Physics at the University of Bremen. The data set is available at the IUP GOME portal http://www.iup.uni-bremen.de/gome/ wfdoas/ (Weber et al., 2007). The limb/nadir matching tropospheric ozone data set used for the comparison with the CCD results is only available for internal use at the moment. In the future, it will be included at the Ozone Climate Change Initiative (CCI) Climate Research Data Package (CRDP; http://www.esa-ozone-cci.org/?q=node/160). The CCD tropical tropospheric ozone data described above will be made available via the GOME portal at IUP and the Ozone Climate Change Initiative (CCI) Climate Research Data Package (CRDP; http://www.esa-ozone-cci.org/?q=node/160).

Acknowledgements. This work was supported in parts by the DLR S5P project (50EE1247) and the federal state of Bremen. The authors would like to thank the principal investigators of the Southern Hemisphere ADditional OZonesondes (SHADOZ) network, P. Valks, K. P. Heue, and the two anonymous reviewers for their helpful comments and suggestions.

The article processing charges for this open-access publication were covered by the University of Bremen.

Edited by: B. Veihelmann

Reviewed by: K.-P. Heue and two anonymous referees

\section{References}

Avery, M., Twohy, C., McCabe, D., Joiner, J., Severance, K., Atlas, E., Blake, D., Bui, T. P., Crounse, J., Dibb, J., Diskin, G., Lawson, P., McGill, M., Rogers, D., Sachse, G., Scheuer, E., Thompson, A. M., Trepte, C., Wennberg, P., and Ziemke, J.: Convective distribution of tropospheric ozone and tracers in the Central American ITCZ region: Evidence from observations during TC4, J. Geophys. Res.-Atmos., 115, D00J21, doi:10.1029/2009JD013450, 2010., 2010.

Beig, G. and Singh, V.: Trends in tropical tropospheric column ozone from satellite data and MOZART model, Geophys. Res. Lett., 34, L17801, doi:10.1029/2007GL030460, 2007. 
Bovensmann, H., Burrows, J. P., Buchwitz, M., Frerick, J., Noël, S., Rozanov, V. V., Chance, K. V., and Goede, A. P. H.: SCIAMACHY: Mission Objectives and Measurement Modes, J. Atmos. Sci., 56, 127-150, doi:10.1175/15200469(1999)056<0127:SMOAMM>2.0.CO;2, 1999.

Boynard, A., Clerbaux, C., Coheur, P.-F., Hurtmans, D., Turquety, S., George, M., Hadji-Lazaro, J., Keim, C., and MeyerArnek, J.: Measurements of total and tropospheric ozone from IASI: comparison with correlative satellite, ground-based and ozonesonde observations, Atmos. Chem. Phys., 9, 6255-6271, doi:10.5194/acp-9-6255-2009, 2009.

Bracher, A., Lamsal, L. N., Weber, M., Bramstedt, K., ColdeweyEgbers, M., and Burrows, J. P.: Global satellite validation of SCIAMACHY $\mathrm{O}_{3}$ columns with GOME WFDOAS, Atmos. Chem. Phys., 5, 2357-2368, doi:10.5194/acp-5-2357-2005, 2005.

Burrows, J. P., Weber, M., Buchwitz, M., Rozanov, V., LadstätterWeißenmayer, A., Richter, A., DeBeek, R., Hoogen, R., Bramstedt, K., Eichmann, K.-U., Eisinger, M., and Perner, D.: The Global Ozone Monitoring Experiment (GOME): Mission Concept and First Scientific Results, J. Atmos. Sci., 56, 151-175, doi:10.1175/1520-0469(1999)056<0151:TGOMEG>2.0.CO;2, 1999.

Burrows, J. P., Bovensmann, H., Bergametti, G., Flaud, J. ., Orphal, J., Noël, S., Monks, P., Corlett, G., Goede, A., von Clarmann, T., Steck, T., Fischer, H., and Friedl-Vallon, F.: The geostationary tropospheric pollution explorer (GeoTROPE) mission: objectives, requirements and mission concept, Adv. Space Res., 34, 682-687, doi:10.1016/j.asr.2003.08.067, 2004.

Callies, J., Corpaccioli, E., and Eisinger, M., Hahne, A., and Lefebvre, A.: GOME-2 - Metop-s second-generation sensor for operational ozone monitoring, ESA Bull. Sp. Agency, 102, 28-36, 2000

Chandra, S., Ziemke, J. R., Duncan, B. N., Diehl, T. L., Livesey, N. J., and Froidevaux, L.: Effects of the 2006 El Niño on tropospheric ozone and carbon monoxide: implications for dynamics and biomass burning, Atmos. Chem. Phys., 9, 4239-4249, doi:10.5194/acp-9-4239-2009, 2009.

Coldewey-Egbers, M., Weber, M., Lamsal, L. N., de Beek, R., Buchwitz, M., and Burrows, J. P.: Total ozone retrieval from GOME UV spectral data using the weighting function DOAS approach, Atmos. Chem. Phys., 5, 1015-1025, doi:10.5194/acp5-1015-2005, 2005.

Cooper, O. R., Parrish, D. D., Ziemke, J., Balashov, N. V., Cupeiro, M., Galbally, I. E., Gilge, S., Horowitz, L., Jensen, N. R., Lamarque, J.-F., Naik, V., Oltmans, S. J., Schwab, J., Shindell, D. T., Thompson, A. M., Thouret, V., Wang, Y., and Zbinden, R. M.: Global distribution and trends of tropospheric ozone: An observation-based review, Elem. Sci. Anthr., 2, 000029, doi:10.12952/journal.elementa.000029, 2014.

Crutzen, P. J.: Photochemical reactions initiated by and influencing ozone in unpolluted tropospheric air, Tellus A, 26, doi:10.3402/tellusa.v26i1-2.9736, 1974.

Crutzen, P. J.: Ozone in the troposphere, in Composition, Chemistry, and Climate of the Atmosphere, 349-393, Reinhold N., New York, 1995.

Cuesta, J., Eremenko, M., Liu, X., Dufour, G., Cai, Z., Höpfner, M., von Clarmann, T., Sellitto, P., Foret, G., Gaubert, B., Beekmann, M., Orphal, J., Chance, K., Spurr, R., and Flaud, J.-M.:
Satellite observation of lowermost tropospheric ozone by multispectral synergism of IASI thermal infrared and GOME-2 ultraviolet measurements over Europe, Atmos. Chem. Phys., 13, 9675-9693, doi:10.5194/acp-13-9675-2013, 2013.

Diab, R. D., Raghunandan, A., Thompson, A. M., and Thouret, V.: Classification of tropospheric ozone profiles over Johannesburg based on mozaic aircraft data, Atmos. Chem. Phys., 3, 713-723, doi:10.5194/acp-3-713-2003, 2003.

Doherty, R. M., Stevenson, D. S., Collins, W. J., and Sanderson, M. G.: Influence of convective transport on tropospheric ozone and its precursors in a chemistry-climate model, Atmos. Chem. Phys., 5, 3205-3218, doi:10.5194/acp-5-3205-2005, 2005.

Ebojie, F., von Savigny, C., Ladstätter-Weißenmayer, A., Rozanov, A., Weber, M., Eichmann, K.-U., Bötel, S., Rahpoe, N., Bovensmann, H., and Burrows, J. P.: Tropospheric column amount of ozone retrieved from SCIAMACHY limb-nadir-matching observations, Atmos. Meas. Tech., 7, 2073-2096, doi:10.5194/amt-72073-2014, 2014.

Fishman, J., Watson, C. E., Larsen, J. C., and Logan, J. A.: Distribution of tropospheric ozone determined from satellite data, J. Geophys. Res., 95, 3599, doi:10.1029/JD095iD04p03599, 1990.

Fortuin, P. J. F. and Kelder, H.: An ozone climatology based on ozonesonde and satellite measurements, J. Geophys. Res., 103, 31709-31734, doi:10.1029/1998JD200008, 1998.

Fueglistaler, S., Dessler, A. E., Dunkerton, T. J., Folkins, I., Fu, Q., and Mote, P. W.: Tropical tropopause layer, Rev. Geophys., 47, RG1004, doi:10.1029/2008RG000267, 2009.

Jacob, D. J.: Introduction to Atmospheric Chemistry, Princeton University Press, 2000.

Jia, J., Rozanov, A., Ladstätter-Weißenmayer, A., and Burrows, J. P.: Global validation of SCIAMACHY limb ozone data (versions 2.9 and 3.0, IUP Bremen) using ozonesonde measurements, Atmos. Meas. Tech., 8, 3369-3383, doi:10.5194/amt-8-3369-2015, 2015.

Gettelman, A. and Forester, P. M. de F.: A Climatology of the Tropical Tropopause Layer., J. Meteorol. Soc. Japan, 80, 911-924, doi:10.2151/jmsj.80.911, 2002.

Hong, G., Yang, P., Gao, B.-C., Baum, B. A., Hu, Y. X., King, M. D., and Platnick, S.: High Cloud Properties from Three Years of MODIS Terra and Aqua Collection-4 Data over the Tropics, J. Appl. Meteorol. Climatol., 46, 1840-1856, doi:10.1175/2007JAMC1583.1, 2007.

IPCC: Climate Change 2007 -The Physical Science Basis: Working Group I Contribution to the Fourth Assessment Report of the IPCC (Climate Change 2007), available at: https://www.ipcc. ch/publications_and_data/ar4/wg1/en/contents.html (last access: July 2016), 2007.

IPCC Working Group 1, I., Stocker, T. F., Qin, D., Plattner, G.-K., Tignor, M., Allen, S. K., Boschung, J., Nauels, A., Xia, Y., Bex, V. and Midgley, P. M.: IPCC, 2013: Climate Change 2013: The Physical Science Basis. Contribution of Working Group I to the Fifth Assessment Report of the Intergovernmental Panel on Climate Change, IPCC, AR5, 1535, 2013

Keim, C., Eremenko, M., Orphal, J., Dufour, G., Flaud, J.-M., Höpfner, M., Boynard, A., Clerbaux, C., Payan, S., Coheur, P.-F., Hurtmans, D., Claude, H., Dier, H., Johnson, B., Kelder, H., Kivi, R., Koide, T., López Bartolomé, M., Lambkin, K., Moore, D., Schmidlin, F. J., and Stübi, R.: Tropospheric ozone from IASI: comparison of different inversion algorithms and validation with 
ozone sondes in the northern middle latitudes, Atmos. Chem. Phys., 9, 9329-9347, doi:10.5194/acp-9-9329-2009, 2009.

Kim, J. H., Newchurch, M. J., and Han, K.: Distribution of Tropical Tropospheric Ozone Determined by the Scan-Angle Method Applied to TOMS Measurements, J. Atmos. Sci., 58, 2699-2708, doi:10.1175/1520-0469(2001)058<2699:DOTTOD>2.0.CO;2, 2001.

Koelemeijer, R. B. A., Stammes, P., Hovenier, J. W., and de Haan, J. F.: A fast method for retrieval of cloud parameters using oxygen A band measurements from the Global Ozone Monitoring Experiment, J. Geophys. Res., 106, 3475, doi:10.1029/2000JD900657, 2001.

Kokhanovsky, A. A., Rozanov, V. V., Burrows, J. P., Eichmann, K.U., Lotz, W., and Vountas, M.: The SCIAMACHY cloud products: Algorithms and examples from ENVISAT, Adv. Space Res., 36, 789-799, doi:10.1016/j.asr.2005.03.026, 2005.

Lelli, L.: Studies of global cloud field using measurements of GOME, SCIAMACHY and GOME-2, PhD Thesis, University of Bremen, 2013.

Lelli, L., Kokhanovsky, A. A., Rozanov, V. V., Vountas, M., and Burrows, J. P.: Linear trends in cloud top height from passive observations in the oxygen A-band, Atmos. Chem. Phys., 14, 56795692, doi:10.5194/acp-14-5679-2014, 2014.

Loschnigg, J. and Webster, P. J.: A Coupled OceanAtmosphere System of SST Modulation for the Indian Ocean, J. Clim., 13, 3342-3360, doi:10.1175/15200442(2000)013<3342:ACOASO>2.0.CO;2, 2000.

Martin, R. V.: Interpretation of TOMS observations of tropical tropospheric ozone with a global model and in situ observations, J. Geophys. Res., 107, 4351, doi:10.1029/2001JD001480, 2002.

Ozone_cci_URD_2.1: Ozone-CCI, available at: http: //www.esa-ozone-cci.org/?q=webfm_send/37, last access: 26 July 2016.

Oltmans, S. J., Johnson, B. J., Harris, J. M., Thompson, A. M., Liu, H. Y., Chan, C. Y., Voemel, H., Fujimoto,T., Brackett,V. G., Chang, W. L., Chen,J.-P., Kim, J. H., Chan, L. Y., and Chang, H.-W.: Tropospheric ozone over the North Pacific from ozonesonde observations, J. Geophys. Res., 109, D15S01, doi:10.1029/2003JD003466, 2004.

Rahpoe, N., von Savigny, C., Weber, M., Rozanov, A. V., Bovensmann, H., and Burrows, J. P.: Error budget analysis of SCIAMACHY limb ozone profile retrievals using the SCIATRAN model, Atmos. Meas. Tech., 6, 2825-2837, doi:10.5194/amt-62825-2013, 2013.

Rex, M., Wohltmann, I., Ridder, T., Lehmann, R., Rosenlof, K., Wennberg, P., Weisenstein, D., Notholt, J., Krüger, K., Mohr, V., and Tegtmeier, S.: A tropical West Pacific $\mathrm{OH}$ minimum and implications for stratospheric composition, Atmos. Chem. Phys., 14, 4827-4841, doi:10.5194/acp-14-4827-2014, 2014.

S5P/TROPOMI Science Verification Report, S5P-IUPL2-ScVR-RP, Richter A. and the Verification Teams: European Space Agency, available at: https://earth. esa.int/web/sentinel/user-guides/sentinel-5p-tropomi/ document-library/-/asset_publisher/w9Mnd6VPjXlc/content/ sentinel-5p-tropomi-science-verification-report (last access: 22 December 2015), 2015.

Sassen, K., Wang, Z., and Liu, D.: Cirrus clouds and deep convection in the tropics: Insights from CALIPSO and CloudSat,
J. Geophys. Res., 114, D00H06, doi:10.1029/2009JD011916, 2009.

Sauvage, B., Thouret, V., Thompson, A. M., Witte, J. C., Cammas, J.-P., Nédélec, P., and Athier, G.: Enhanced view of the "tropical Atlantic ozone paradox" and "zonal wave one" from the in situ MOZAIC and SHADOZ data, J. Geophys. Res., 111, D01301, doi:10.1029/2005JD006241, 2006.

Seinfeld, J. H. and Pandis, S. N.: Atmospheric Chemistry and Physics: From Air Pollution to Climate Change, available at: http://eu.wiley.com/WileyCDA/WileyTitle/ productCd-1118947401.html (last access: July 2016), 2016.

Schumann, U. and Huntrieser, H.: The global lightning-induced nitrogen oxides source, Atmos. Chem. Phys., 7, 3823-3907, doi:10.5194/acp-7-3823-2007, 2007.

Shindell, D. T., Faluvegi, G., Koch, D. M., Schmidt, G. A., Unger, N., and Bauer, S. E.: Improved attribution of climate forcing to emissions, Science, 326, 716-718, doi:10.1126/science.1174760, 2009.

Sierk, B., Richter, A., Rozanov, A., Savigny, C. von, Schmoltner, A. M., Buchwitz, M., Bovensmann, H., and Burrows, J. P.: Retrieval And Monitoring of Atmospheric Trace Gas Concentrations in Nadir and Limb Geometry Using the Space-Borne Sciamachy Instrument, Environ. Monit. Assess., 120, 65-77, doi:10.1007/s10661-005-9049-9, 2006.

Sherwood, S. C. and Dessler, A. E.: A model for transport across the tropical tropopause, J. Atmos. Sci., 58, 765-779, 2001.

Stevenson, D. S., Dentener, F. J., Schultz, M. G., Ellingsen, K., van Noije, T. P. C., Wild, O., Zeng, G., Amann, M., Atherton, C. S., Bell, N., Bergmann, D. J., Bey, I., Butler, T., Cofala, J., Collins, W. J., Derwent, R. G., Doherty, R. M., Drevet, J., Eskes, H. J., Fiore, A. M., Gauss, M., Hauglustaine, D. A., Horowitz, L. W., Isaksen, I. S. A., Krol, M. C., Lamarque, J. F., Lawrence, M. G., Montanaro, V., Müller, J. F., Pitari, G., Prather, M. J., Pyle, J. A., Rast, S., Rodriguez, J. M., Sanderson, M. G., Savage, N. H., Shindell, D. T., Strahan, S. E., Sudo, K., and Szopa, S.: Multimodel ensemble simulations of present-day and near-future tropospheric ozone, J. Geophys. Res., 111, D08301, doi:10.1029/2005JD006338, 2006.

Stevenson, D. S., Young, P. J., Naik, V., Lamarque, J.-F., Shindell, D. T., Voulgarakis, A., Skeie, R. B., Dalsoren, S. B., Myhre, G., Berntsen, T. K., Folberth, G. A., Rumbold, S. T., Collins, W. J., MacKenzie, I. A., Doherty, R. M., Zeng, G., van Noije, T. P. C., Strunk, A., Bergmann, D., Cameron-Smith, P., Plummer, D. A., Strode, S. A., Horowitz, L., Lee, Y. H., Szopa, S., Sudo, K., Nagashima, T., Josse, B., Cionni, I., Righi, M., Eyring, V., Conley, A., Bowman, K. W., Wild, O., and Archibald, A.: Tropospheric ozone changes, radiative forcing and attribution to emissions in the Atmospheric Chemistry and Climate Model Intercomparison Project (ACCMIP), Atmos. Chem. Phys., 13, 3063-3085, doi:10.5194/acp-13-3063-2013, 2013.

Thompson, A. M., Witte, J. C., McPeters, R. D., Oltmans, S. J., Schmidlin, F. J., Logan, J. A., Fujiwara, M., Kirchhoff, V. W. J. H., Posny, F., Coetzee, G. J. R., Hoegger, B., Kawakami, S., Ogawa, T., Johnson, B. J., Vömel, H., and Labow, G.: Southern Hemisphere Additional Ozonesondes (SHADOZ) 1998-2000 tropical ozone climatology 1. Comparison with Total Ozone Mapping Spectrometer (TOMS) and ground-based measurements, J. Geophys. Res., 108, 8238, doi:10.1029/2001JD000967, 2003. 
Valks, P. J. M., Koelemeijer, R. B. A., van Weele, M., van Velthoven, P., Fortuin, J. P. F., and Kelder, H.: Variability in tropical tropospheric ozone: Analysis with Global Ozone Monitoring Experiment observations and a global model, J. Geophys. Res., 108, 4328, doi:10.1029/2002JD002894, 2003.

Valks, P., Hao, N., Gimeno Garcia, S., Loyola, D., Dameris, M., Jöckel, P., and Delcloo, A.: Tropical tropospheric ozone column retrieval for GOME-2, Atmos. Meas. Tech., 7, 2513-2530, doi:10.5194/amt-7-2513-2014, 2014.

Valks, P., Loyola, D., Hao, N., Rix, M., and Slijkhuis, S.: Algorithm Theoretical Basis Document for GOME-2 Total Column Products of Ozone, Minor Trace Gases and Cloud Properties(GDP 4.5 for O3M-SAF OTO and NTO), DLR/GOME-2/ATBD/01, Iss./Rev.: 2/E, available at: http://atmos.eoc.dlr.de/gome2/docs/ DLR_GOME-2_ATBD.pdf, 2015.

Wang, P., Stammes, P., van der A, R., Pinardi, G., and van Roozendael, M.: FRESCO+: an improved $\mathrm{O}_{2}$ A-band cloud retrieval algorithm for tropospheric trace gas retrievals, Atmos. Chem. Phys., 8, 6565-6576, doi:10.5194/acp-8-6565-2008, 2008.

Weber, M., Lamsal, L. N., Coldewey-Egbers, M., Bramstedt, K., and Burrows, J. P.: Pole-to-pole validation of GOME WFDOAS total ozone with groundbased data, Atmos. Chem. Phys., 5, 1341-1355, doi:10.5194/acp-5-1341-2005, 2005.

Weber, M., Lamsal, L. N., and Burrows, J. P.: Improved SCIAMACHY WFDOAS total ozone retrieval: Steps towards homogenising long-term total ozone datasets from GOME, SCIAMACHY, and GOME2, Proc. Envisat Symposium 2007, Montreux, Switzerland, 23-27 April 2007, ESA SP-636, 2007.

Weber, M., Chehade, W., Fioletov, V. E., Frith, S. M., Long, C. S., Steinbrecht, W., and Wild, J. D.: [Global Climate] Stratospheric ozone, in: State of the Climate in 2012, B. Am. Meteor. Soc., 94, S36-S37, 2013.

WHO: Health risks of particulate matter from longrange transboundary air pollution, available at: http: //www.euro.who.int/_data/assets/pdf_file/0006/189051/

Health-effects-of-particulate-matter-final-Eng.pdf (last access: 26 July 2016), 2013.

Yonemura, S., Tsuruta, H., Kawashima, S., Sudo, S., Peng, L. C., Fook, L. S., Johar, Z., and Hayashi, M.: Tropospheric ozone climatology over Peninsular Malaysia from 1992 to 1999, J. Geophys. Res., 107, doi:10.1029/2001JD000993, 2002.
Ziemke, J. R. and Stanford, J. L.: Kelvin waves in total column ozone, Geophys. Res. Lett., 21, 105-108, doi:10.1029/93GL03287, 1994.

Ziemke, J. R., Chandra, S., and Bhartia, P. K.: Two new methods for deriving tropospheric column ozone from TOMS measurements: Assimilated UARS MLS/HALOE and convective-cloud differential techniques, J. Geophys. Res., 103, 22115-22127, doi:10.1029/98JD01567, 1998.

Ziemke, J. R., Chandra, S., and Bhartia, P. K.: "Cloud slicing": A new technique to derive upper tropospheric ozone from satellite measurements, J. Geophys. Res., 106, 9853-9867, doi:10.1029/2000JD900768, 2001.

Ziemke, J. R., Chandra, S., Duncan, B. N., Froidevaux, L., Bhartia, P. K., Levelt, P. F., and Waters, J. W.: Tropospheric ozone determined from Aura OMI and MLS: Evaluation of measurements and comparison with the Global Modeling Initiative's Chemical Transport Model, J. Geophys. Res., 111, D19303, doi:10.1029/2006JD007089, 2006.

Ziemke, J. R., Joiner, J., Chandra, S., Bhartia, P. K., Vasilkov, A., Haffner, D. P., Yang, K., Schoeberl, M. R., Froidevaux, L., and Levelt, P. F.: Ozone mixing ratios inside tropical deep convective clouds from OMI satellite measurements, Atmos. Chem. Phys., 9, 573-583, doi:10.5194/acp-9-573-2009, 2009.

Ziemke, J. R., Chandra, S., Duncan, B. N., Schoeberl, M. R., Torres, O., Damon, M. R., and Bhartia, P. K.: Recent biomass burnings in the tropics and related changes in tropospheric ozone, Geophys. Res. Lett., 36, L15819, doi:10.1029/2009GL039303, 2009b.

Ziemke, J. R., Chandra, S., Oman, L. D., and Bhartia, P. K.: A new ENSO index derived from satellite measurements of column ozone, Atmos. Chem. Phys., 10, 3711-3721, doi:10.5194/acp10-3711-2010, 2010.

Ziemke, J. R. and Chandra, S.: Development of a climate record of tropospheric and stratospheric column ozone from satellite remote sensing: evidence of an early recovery of global stratospheric ozone, Atmos. Chem. Phys., 12, 5737-5753, doi:10.5194/acp-12-5737-2012, 2012. 